Tér és Társadalom 16. évf. 2002/1. 59-98. p.

Tér és Társadalom

XVI. évf. 2002 1: 59-98

\title{
KISALFÖLDI ÉS ALFÖLDI MEZŐVÁROSOK KÜLÖNBÖZÖSÉGE, KISVÁROSI ÉRTÉKEK VÉDELME
}

\author{
(The Difference between the Market-Towns in the Great \\ Hungarian Plain and the Small Hungarian Plain, \\ Protection of Small Town Values)
}

SOMFAI ATTILA

Kulcsszavak:

mezöváros falu középkor jellegvédelem telepuilési alaprajz

Magyarországon sajátságos kontraszt figyelhetó meg a két nagy országrészre (a Dunántúlra, ill. az Alföldre) jellemzó történeti településfejlödésben. A történetileg kialakult falvak és mezövárosok településszerkezete a morfológiai felépítés szerint két fö csoportba sorolhatớ: a Dunántúlra (és tgy az Észak. Dunántülon található Kisalföldre is) jellemzök a soros felépitésủ telepszerü települések, az Alföldön pedig megtalálhatók a kétbeltelkes felépitésü halmazos települések is, antelyek többsége közel kör alakú. A két fö csoporton belïl számos altipus lehetséges. Egyes altípusok a késöbbi korokban hozzáizesult településrészek miatt ma már nehezen ismerhetök fel, és a történeti településszerkezet nagymérvü megváltoztatására is akad példa.

A történeti települések vizsgálata megmutatja, hogy az „indokolatlanul szabálytalannak" hitt történeti településalaprajz föbb elemeit számos esetben a topográfiai adottságok határozták meg és részben ennek köszönhetik „egyszeri és megismételhetetlen” arculatukat. Ez a felismerés a településtervezöket a történeti telepullésszövet jobb megbecsülésére ösztönözheti, és hozzájárulhat a gyakorlati telepulléstervezés napjainkban tapasztalható szemléletváltozásához. A települések fejlesztésekor már nem csupán egyes müemléképületek, épületegyüttesek, utcák, terek védelme a cél, hanem az egész épitett települési környezet és az öt befogadó táji környezet integrált védelme, az ún. jellegvédelem.

\section{Témafelvetés, a kutatás idöszerüsége}

Magyarország egy új fellendülés korszakának küszöbén áll. A területfejlesztésben politikai szándék és egyben gazdasági szükségszerüség is, hogy a vidék nagyobb szerepet kapjon. A túlzott centralizáció évtizedeinek elmúltával a nagy-és középvárosok mellett szükség lesz újabb gazdasági és ellátó-szervezỏ alközpontokra. A hazai városhálózatban Budapest és a 22 megyei jogú város mellett jelenleg kb. 210 középváros és kisváros szerepel, ebból 100-as nagyságrendú (!) a kisvárosok száma - mégis a településhálózat jövőképét illetỏen a kisvárosokra meglehetỏsen kevés figyelem jut.

A vidékfejlesztés fő pólusai továbbra is várhatóan a vidéki nagyvárosok lesznek, azonban a vidék felemelkedésében a kisebb települések is egyre fontosabb szerepet tölthetnek be. Ezért is különösen időszerủ, hogy a mezővárosi léptékủ-típusú települések fejlődését történeti távlatokban vizsgáljuk, és értékeik ismeretében jövőjüket kedvezően befolyásolhassuk. - Százharminc évvel a mezőváros, mint közigazgatási kategória megszüntetése után természetesen nem lehet újra a hagyományos 
Somfai Attila : Kisalföldi és alföldi mezővárosok különbözősége, kisvárosi értékek védelme.

Tér és Társadalom 16. évf. 2002/1. 59-98. p.

mezővárosban gondolkodni, ill. a mezőváros-hálózatot egy az egyben feltámasztani, de valamilyen kisváros kategóriára érezhetően szükség lehet. A történeti elemzéseken túl indokolt az azóta eltelt idő agrárvárosi folyamatainak komplex elemzése, jövőbe mutató tanulságok megfogalmazása.

Magyarországon nagy számú mezỏváros volt 1876-ig. Az ország területén viszonylag sủrủn és egyenletesen helyezkedtek el. A volt mezővárosok egy része ellátó szerepkörében és építészeti arculatában örzi múltját, mások alig különböznek a falvaktól. Az eddigi történeti kutatások az Alföld településeit sajátságosabbnak vélték, így a dunántúliakhoz képest behatóbban vizsgálták. Jelen írásból kiderül, hogy a Kisalföldön is számos mezövárosi életút-típus különíthető el, eközben kirajzolódik a dunántúli és alföldi települések eltérő fejlödése is.

\section{A magyar mezövárosok kialakulása, fejlödésük történelmi sajátosságai}

A mezővárosok (ún. oppidumok) a magyar vidéki településstruktúrában nagyon fontos szerepet töltöttek be. Falusias jellegü, de városi kiváltságokkal rendelkezö települések voltak, melyek - szemben a szabad királyi városokkal (ún. civitasok) legtöbbször földesúri vagy egyházi (püspöki) fennhatóság alatt álltak. A mezővárosi címet föleg a középkorban adományozták. A mezőváros elnevezés 1876-ban, a kőzigazgatás gyökeres átszervezésével megszünt. Egy részüket községgé minősítették, kisebb részüket pedig várossá.

Mezővárosaink fejlődésében néhány fỏ vizsgálati szempont alapján jól körvonalazhatók a föbb hasonlóságok és eltérések. Ezek a társadalmi-gazdasági arculat, a feudális hatalom formája (és a hatalom ellenében kifejtett önrendelkezési törekvések eredményessége) és nem utolsó sorban a településszerkezeti sajátosságok.

Azon települések kialakulásában, melyek később mezővárosi rangot kaptak, számos tényező játszott szerepet. Leggyakrabban valamilyen helyi értéket, sőt értékek halmozódását fedezhetjük fel. Védelmi értékeket (vár-hegy, víz, mocsár közelsége), kereskedelmi-megközelíthetőségi értékeket (út-csomópont, folyóátkelés), lakhatással összefüggő értéket (topográfiailag magasvíztöl védett területek) és gazdálkodási-megélhetési értékeket (halászhelyek, erdöségek, legelők, jó termőterületek közelsége). A megnevezett helyi értékek közül úgy tủnik, az egyik legerősebbnek a vásárfunkció bizonyult. Nem véletlen, hogy a II. József-féle katonai felmérési térképen a mezővárosokat „Markt” (piac) megjelöléssel illették.

A mezővárosok kialakulását, fejlődését az értékek mellett politikai, szellemi erők alapvetően befolyásolták: a világi (feudális uraságok, ill. városok irányító testülete) vagy egyházi hatalom, befolyás (püspökségek, monostorok). Nemcsak közvetlenül feudális uraságoktól, hanem szabad királyi városoktól vagy más mezővárosoktól is függhettek mezỏvárosok (pl. a Sopron vármegyei Kismarton-váralja, Fraknóváralja stb). 
Somfai Attila : Kisalföldi és alföldi mezővárosok különbözösége, kisvárosi értékek védelme. Tér és Társadalom 16. évf. 2002/1. 59-98. p.

TÉT XVI. évf. 2002

Kisalföldi és alföldi mezövárosok ...

61

Az első városias településekröl a 12-13. századi okleveles említésekböl tudunk. Az 1390 elötti forrásaink közel 50 mezövárost említenek - sokszor váltakozva, nem következetesen - civitas vagy oppidum néven. A mezővárosi rangok elterjedését a városi kiváltságok szaporodásával összhangban a 15. századra tehetjük. Ekkor már érzékelhető különbség mutatkozik a mezögazdaság mellett föleg kereskedelemmel és iparral foglalkozó civitasok (királyi városok), valamint az agrárjellegüket fejlödő kézmüiparuk ellenére megörzö oppidumok (földesúri mezővárosok) között. A 16-17. században számos település lakói mezővárosi kiváltságaikat katonai szolgálataik fejében kapták (pl. a Kisalföldön Kapuváron vagy a hajdúsági mezővárosokban pl. Hajdúböszörményben stb.).

Történeti irodalmunk 800-850-re becsüli a 15. század végi mezövárosok számát. Bácskai Vera kutatásai e feltevést igazolják: Erdélyt és Szlavóniát figyelmen kívül hagyva a 15. század végéig mintegy 750 települést említenek oppidum néven, erről a csupán véletlenszerủen fennmaradt oklevelekből tudunk. Grafikonon ábrázolva szembetünő a mezővárosok számának növekedése Zsigmond király (1387-1437) és még inkább Mátyás király (1458-1490) uralkodásának idején (1., 2. ábra).

\section{I. ÁBRA}

Újabb oppidumok okleveles említései 1350 és 1530 között tizévenkénti bontásban

(The Mention of Further Oppidums in Documents between 1350 and 1530 by decades)

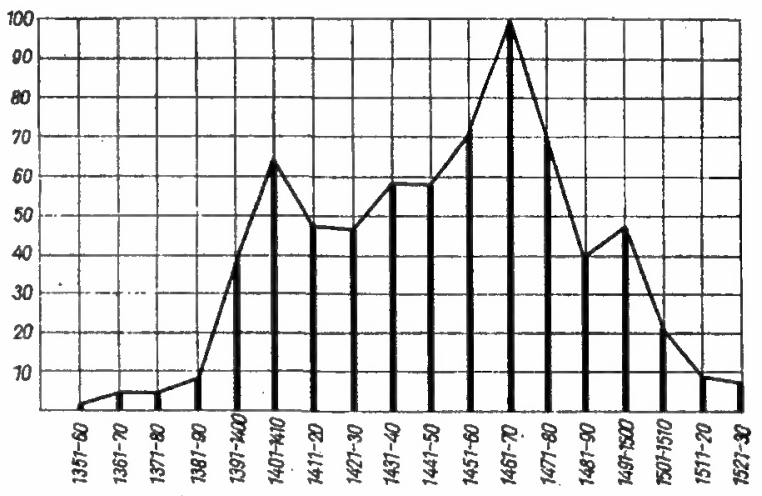

Forrás: Bácskai 1965.

A 15. század végén az oppidumok átlagnépessége 500 fö körül mozgott. Ez a szám ötszöröse volt a falvak átlagnépességének, de jóval alatta maradt a legtöbb civitas lélekszámának. A népességnek átlagosan az egyötöde élt mezővárosokban, ez az arány egyes vármegyékben vagy uradalmakban még magasabb volt (pl. a Sárvár-kapuvári uradalomban a népesség fele). 


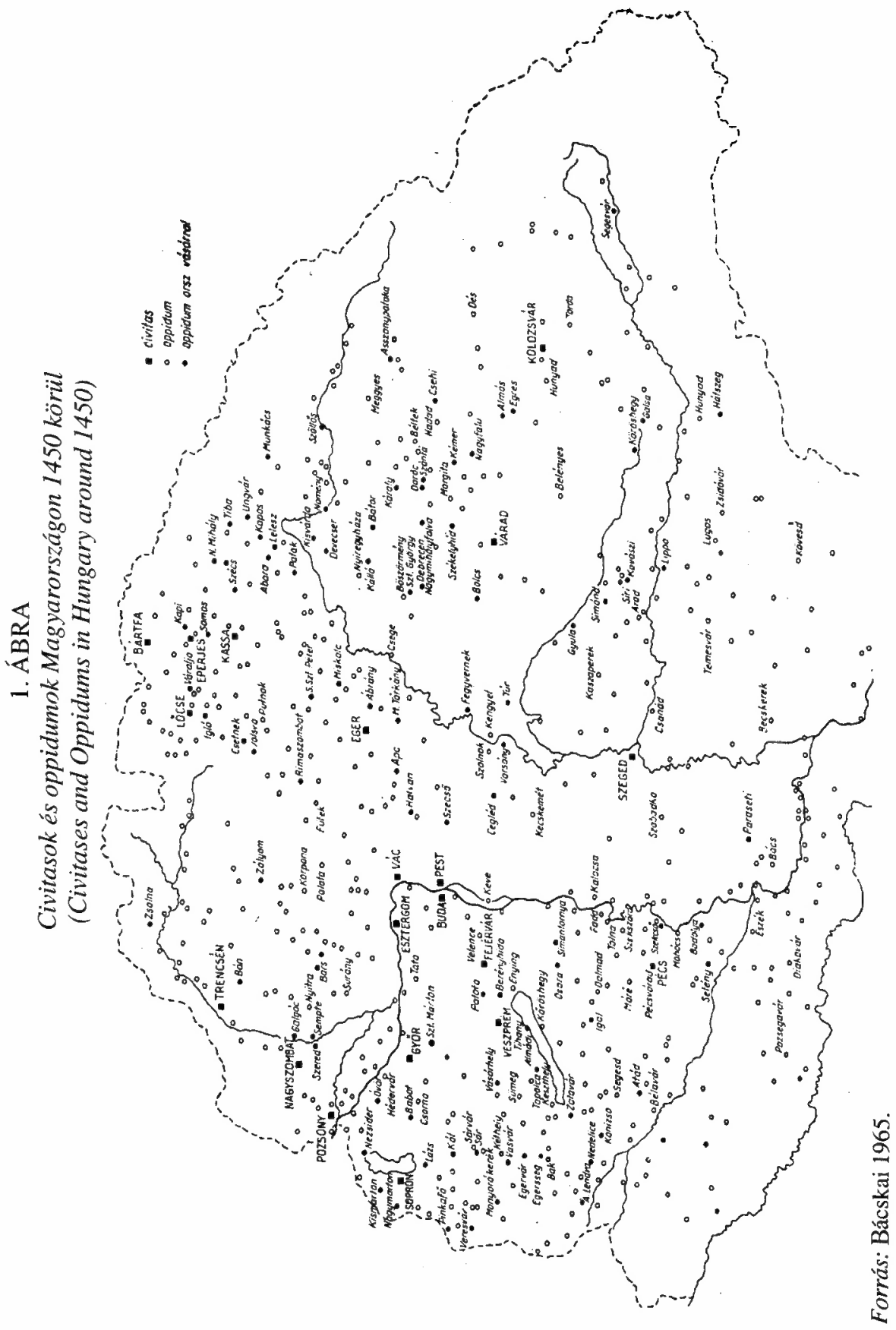


Somfai Attila : Kisalföldi és alföldi mezővárosok különbözősége, kisvárosi értékek védelme. Tér és Társadalom 16. évf. 2002/1. 59-98. p.

Az oppidumok és a nagyobb falvak közti minőségi különbséget nem az említett eltérő népességszám, hanem inkább a mezögazdaság árutermelő jellege, az eltéró tulajdonviszonyok (a jobbágy eladhatta telkét), ill. a kézmúves lakosság nagyobb aránya (a 15. században esetenként közel 20\%) jelentette. A Dunántúl kitünő éghajlati- és talajadottságai kedveztek a mezỏgazdálkodásnak (Györi 1999), pl. bort termeltek eladásra, ill. tájspecifikus növényeket termesztettek. Ezzel szemben az alföldi pusztai legelők leggazdaságosabb hasznosítása a külterjes állattenyésztés volt. A termékeket nem csak helyi és környékbeli vásárokon értékesítették - marhák, lovak ezreit hajtották a határon túlra, pl. Bécsbe. A 15. századi magyar külkereskedelem $60 \%$-át jelentỏ állatkivitel elsősorban az alföldi mezővárosokból került ki. A mezőgazdálkodást kiszolgáló kézműipar továbbfejlődésével a 18. századra céhek jöttek létre (Bácskai 1965).

Az alföldi mezővárosok lakossága a falvakéval összehasonlítva lényegesen szabadabb körülmények között gazdálkodhatott. Ez vagyoni és társadalmi differenciálódáshoz vezetett. A közösség egyes tagjai jobban kiemelkedtek, és a rátermettebb gazdák idóvel nemességet kaphattak (Kecskeméten, Nagykőrósön) - ez a város világi földesurának legtöbbször érdekében állt, míg az egyházi irányítás alatt álló városokban kevésbé (Cegléden). Az így kiemelkedett gazdák a mezővárosok irányító testületében a város földterületeinek növelésén, a viszonylagos autonómia elömozdításán fáradoztak. A földesúri terheket egy összegben (census) válthatták meg a jobbágyok, s ez a cenzuális viszony elósegítette az autonóm szervezet kiépülését. A földesúr mezővárosának jövedelmezósége érdekében további privilégiumokat igyekezett szerezni. Az alföldi mezővárosok viszonylagos önállóságát még a török időkben is sikerült megőrizni. A török időkben ugyan megtorpant az alföldi mezővárosok fejlődése, de mint kiváltságos szultáni birtokok, ún. hász városi rangot nyertek (Kecskemét, Nagykőrös, Cegléd, Kiskunhalas, Jászberény, Hódmezóvásárhely, Mezötúr és Ványa). A török kiüzését követően, de még inkább a 18. század elejétől a mezővárosok tágas határának eltartóképessége a népesség-növekedéssel fokozatosan telítődött, s ez a mezővárosi társadalom további differenciálódásához, az alsóbb rétegek elszegényedéséhez vezetett. Az alföldi mezóvárosok a földesúri befolyás fokozatos lazításáért, minél nagyobb fokú autonómia eléréséért küzdöttek. A polgárias fejlődés azon mezővárosokban indulhatott meg legelőbb, melyek a feudális kötelezettségek megváltásával - ill. a századfordulón a földesúr földjeinek megvásárlásával - hamarabb szabadultak a feudális földesúri vagy egyházi függőségből.

A középkorban Észak-Dunántúl nagy része nem volt török hódoltsági terület, hanem a királyi Magyarország részét képezte. A mezővárosok mégsem fejlödhettek viszonylagosan háborítatlanul, mint a hódoltsági területek mezővárosai. A török portyázások állandóan félelemben tartották az észak-dunántúli települések lakosságát, különösen nagy pusztítást végeztek Bécs egy-egy sikertelen ostroma kapcsán. Győr vármegye Pusztai járásának neve is erre utal (Lengyel 1944). Győr térségében nemcsak a kisebb falvak, hanem olyan nagyobb települések is eltüntek a föld színé- 
Somfai Attila : Kisalföldi és alföldi mezővárosok különbözősége, kisvárosi értékek védelme.

Tér és Társadalom 16. évf. 2002/1. 59-98. p.

röl, melyek később talán mezövárossá válhattak volna. A Sokoró vonulatától keletre a települések ritkasága még ma is szembetủnő, mivel csak egy részüik tudott újjáéledni. A török idők elmúltával a korábban védelmi feladatokat ellátó mezövárosok lakosságának katonai feladatai csökkentek. A földesurak ezért igyekeztek kiváltságaikat megnyirbálni, a jobbágyterheket súlyosbítani. A Kisalföld nagyobb részén az erdők kiirtásával földesúri nagybirtokok jöttek létre (pl. Sopron vármegyében az Esterházyak uradalma), melyeken majorgazdálkodást folytattak. A 17. század közepére a jobbágyterhek - ajándékozási kötelezettség, robot, terményadó, pénzadó stb. - egyre csak súlyosbodtak (Mikó 1968), a 18. században pedig már az állam is megnövekedett igényeket támasztott. A földesurak a majorgazdálkodás kiterjesztése, az állam főként az állandó hadsereg fenntartásának költsége miatt kívánt mind nagyobb terheket rakni a parasztság vállára. Emiatt a dunántúli megyék panaszos kérvényeket küldtek Mária Teréziához. A kormányzatnak érdekében állott, hogy a földesúri terheknek határt szabjon: 1767 és 1774 között az ország 66 megyéjéböl 44-ben megtörtént az úrbérrendezés - ez alól kivételt csupán a kiváltságos jász-kun terület és a hajdúvárosok jelentettek a szükebb értelemben vett Magyarországon (Felhö 1970). A Kisalföldön a 19. század második felétỏl meginduló polgárosodást a kereskedelem, a céhes kereteket meghaladó ipari vállalkozások, városközpontok fokozódó urbanizálódása, igazgatási funkciók egyre nagyobb koncentrációja jelezte. A századfordulóra új típusú szolgáltatások is megjelentek (jogszolgáltatás, többszintủ iskolai szerepkör).

A mezőváros településkategóriát a 19. század végén már a feudális idők emlékének tekintették. A kiegyezést követỏen 1871-ben átfogó közigazgatási átszervezést hajtottak végre, ekkor a mezőváros kategória megszủnt, és a szabad királyi városok szerepköre is lényegesen átalakult. A 12000 főnél népesebb szabad királyi városok (pl. Györ és Sopron) és egyes kivételes mezővárosok (a Kisalföldön pl. Szombathely, az Alföldön pl. Kecskemét) magasabb szerepkörü, ún. törvényhatósági jogú városi rangot kaptak, míg más szabad királyi városok (a Kisalföldön pl. Köszeg, Kismarton, Ruszt), ill. mezővárosok (a Kisalföldön pl. Pápa, az Alföldön pl. Cegléd, Nagykőrös) pedig rendezett tanácsú város címet. Az Északnyugat-Dunántúlon a korábbi sürủ mezőváros-hálózatot nem tartották meg. Például Kapuvár mezỏváros 1871-ben nagyközség lett, s csak száz évvel később, 1969-ben lett újra város.

Észak-Dunántúlon, kủlönösen Sopron vármegyében a mezőgazdaság tőkés fejlödése a 19. század derekától gyorsabb volt, mint az ország más részeiben (Simkovits 1965). Általános tendencia a nagybirtokok koncentrálódása és ezzel párhuzamosan a kisbirtokok elaprózódása. Az elszegényedett településlakók többsége számára a kibontakozó gazdasági fejlödés és a meginduló polgárosodás nem hozott érezhető javulást, sőt a technikai fejlödés a munkanélküliség növekedését eredményezte. A föld- és lakótelekínség, kilátástalan életkörülmények miatt a századfordulón a lakosság jelentékeny hányada vándorolt ki Amerikába. 
Somfai Attila : Kisalföldi és alföldi mezővárosok különbözősége, kisvárosi értékek védelme. Tér és Társadalom 16. évf. 2002/1. 59-98. p.

\section{A kisalföldi és alföldi mezövárosok eltérö fejlódése, különös tekintettel a település alaprajzra}

\section{Mezövárosaink építészetének fóbb vonásai}

Mezővárosaink tágabb értelemben vett építészete - a településhálózat, település arculata, építészeti karaktere - a mezỏvărosias fejlödésnek és a társadalmigazdasági viszonyoknak kifejezője. Az építészeti arculat átalakulásában az elemi károk (tủzvészek, árvizek) és a háborúk (elnéptelenedést követő telepítések) is igen jelentős szerepet játszottak.

A 19. század derekáig mezővárosaink építészetét a mezögazdálkodási jelleg határozta meg. Jó példa erre a dunántúli települések hagyományos oldalhatáros (fésüs) beépítése, amelyböl fakadóan az épületek oromfalakkal fordultak az utca felé (3. ábra). A keskeny telket jól kihasználó, eredendően mezőgazdasági jellegú oldalhatáros beépítés számos településen máig fennmaradt, sỏt tovább él.

Az oldalhatáros beépítésmódból következő térbeli rend nem jelentett egyhangúságot. $\mathrm{Az}$ épületek egyéniségét a tájegységenként és épületenként eltérö építöanyaghasználat (pl. vályog, kỏ, fa), eltérỏ tetőforma (pl. kontyolt vagy oromzatos), eltérő tornácmegoldások (pl. boltíves gádor vagy oszlopos tornác) és homlokzati díszítésvilág (pl. dunántúli vakolatdíszek, szegedi sugaras faoromzat) hordozta.

\section{3. ÁBRA}

Oldalhatáros beépitésü utcarészlet Fertôrákoson

(Characteristic Street Part in Fertörákos)

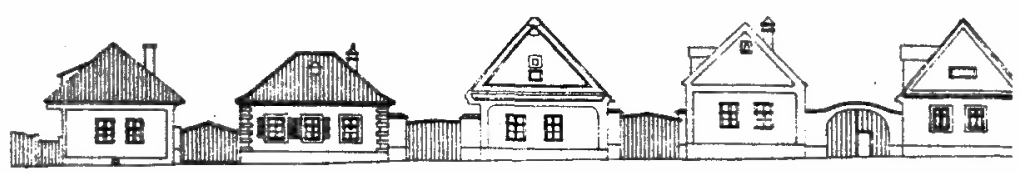

Forrás: Martin 1994.

Korábban az årvizek, belvizek korlátozták egyes mezővárosok területi fejlődését. A népesség növekedése nagymérvü telekaprózódáshoz, a települések eröteljes besürüsödéséhez vezetett. A folyószabályozások ellenére a századfordulóra fokozott lakótelek-hiány és fokozott termőföld-ínség alakult ki, mivel a várt földosztás nem történt meg (Soproni 1940). A kisalföldi gazdák - hasonlóan az ország más részeihez - számos településen kényszerüségből eladták szalagtelkük udvarának egy részét, ahol a vevő (vagy épp a gazda rokonai) építettek egymás mögé zsúfolódó újabb és újabb házakat (Göcsei 1943). Az egyes szalagtelkeken sok esetben 6-8 ház is következett egymás után, elkerítés nélkull (4. ábra). A később tervezett új utcákkal gyakran a hosszan elnyúló szalagtelkek hátsó részét szelték keresztül. 
Somfai Attila : Kisalföldi és alföldi mezővárosok különbözősége, kisvárosi értékek védelme.

Tér és Társadalom 16. évf. 2002/1. 59-98. p.

\section{4. ÁBRA}

Szalagtelken folytatólagosan egymás mögé épített lakóházak Kapuváron, 1870-es térképen

(Continuously in Close Order Astern Built Houses in Long Ground-plots in Kapuvár in 1870)

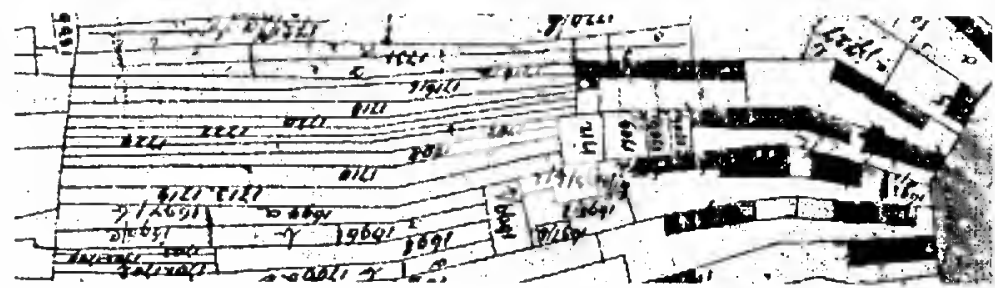

Forrás: Soproni Levéltár.

A sorozatos tủzpusztítások az építészet fejlődését indukálták elsősorban a városszabályozás napirendre tüzésével, korszerủbb építőanyagok felhasználásával (cserépfedés, téglafalazatok). A 19. század utolsó harmadában a városi tanácsok építészeti hatósága már szabályrendeletekbe rögzítve, városrendezési eszközökkel irányította a városkép alakulását (5-6. ábra) és az építkezés módját, ti. többek között kötelezövé tették a leendő épületek tervrajzainak elkészíttetését is. Ez korszerübb, egészségesebb lakásviszonyok kialakulását eredményezte.

\section{5. ÁBRA}

Jellegzetes alföldi halmaztelepuilés részlete.

Mezötárkány az 1869. évi kataszteri térképen

(Part of a Typical Cluster-type Settlement in the Great Hungarian Plain.

Mezötárkány in the Cadastre Map in 1869)

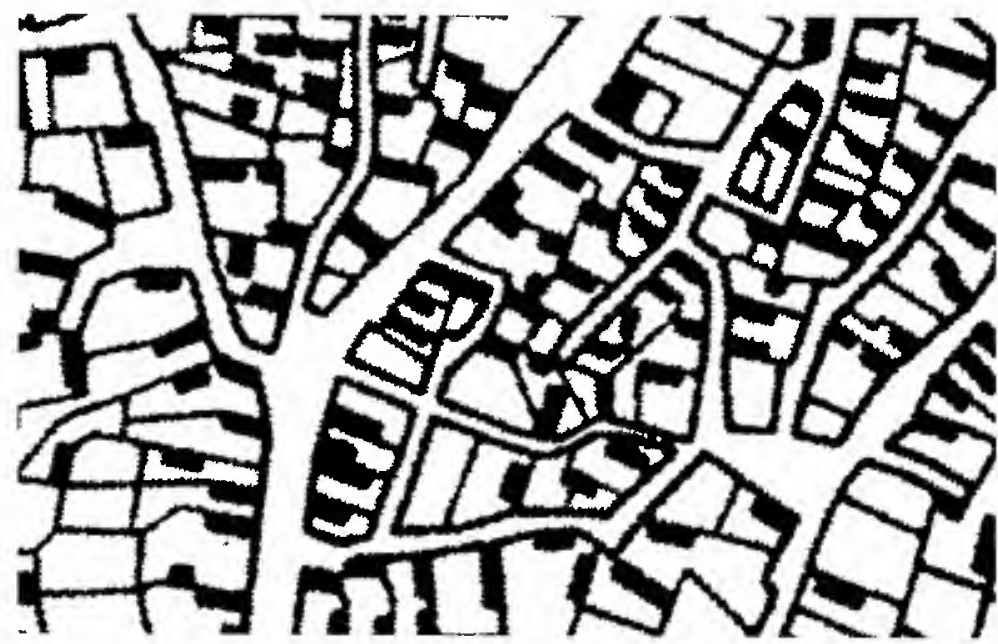

Forrás: Mendöl 1963. 
Somfai Attila : Kisalföldi és alföldi mezővárosok különbözősége, kisvárosi értékek védelme. Tér és Társadalom 16. évf. 2002/1. 59-98. p.

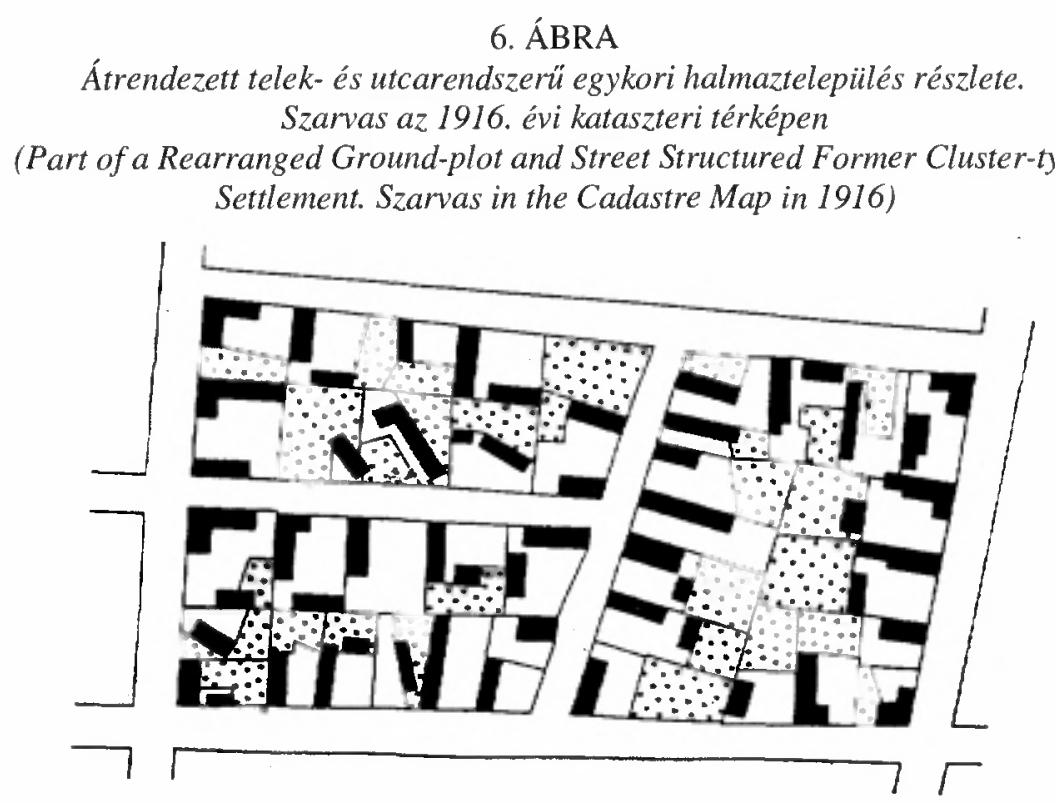

Forrás: Mendöl 1963.

A hagyományos, korszerütlen építkezés a 19. században a mezővárosok peremrészére szorult vissza. Mind az úri, polgári és parasztpolgári építészetben stílusjellegek jelennek meg, a tulajdonosok javuló társadalmi-gazdasági lehetőségeihez mérten. Megfigyelhető romantikus, eklektikus, historizáló, szecessziós stílusjegyek követése. A sajátságos, változatos díszítőmüvészet a mezővárosi építészetet mutatósabbá, rangosabbá tette. Ez a századvégre még színesebbé, stílusosabbá válik, mégis megörzi a mezővárosi építkezés hagyományait is. A 19. század végétől pl. a Rábaközben jellemzök a népi építészettöl a polgári építészet felé mutató átmeneti korszak szabadon álló, „L” alaprajzú gazdaházai, az ún. rábaközi négyablakosok is.

A 19. század második felében a polgárosodást a legrangosabb utcák zártsorúsodása, a városközpont épületeinek emeletesedése jelzi. A Dunántúlon ez a városias mag általában nagyobb, az Alföldön viszont kisebb a szélesen elterülö falusias városrészekhez képest.

A 19. század végén és különösen a századfordulón a gazdasági prosperitást a magánépítkezések mellett nagy mérvủ középítkezések jellemzik: városháza-, iskola-, kôrház-, kisdedóvó- és kaszárnyaépítés, pénzügyi és kereskedelmi létesítmények (bankok, bazårok). Korszerü, többszintes lakástömbök, egyházi vagy világi bérházak épülnek.

Az első világháború törést hozott a szêp ívü fejlödésben, és a két háború közötti időszak sem hasonlitott már a korábbi fénykorhoz. További középületek építése és az úri társadalom villaépítkezései ugyan a fejlődést mutatták, de a paraszti, parasztpolgári építkezések lanyhultak, amelynek fỏ oka a gazdasági világválság volt. A szociális nehézségek enyhítésére állami programot valósítottak meg. Az 1940 körüli években került sor az ONCSA-építkezésekre. A települések területének jobb ki- 
Somfai Attila : Kisalföldi és alföldi mezővárosok különbözősége, kisvárosi értékek védelme.

Tér és Társadalom 16. évf. 2002/1. 59-98. p.

használását új típusú városrendezési eszközökkel - pl. tömbbelsöt feltáró lakóutcákkal - is igyekeztek elömozdítani. Ez azért volt lehetséges, mert a városbelső lakosságának életvitele alapjaiban megváltozott, már nem a mezögazdálkodás determinálta a telekalakítást és telekhasználatot.

A 19. század végéig az ország ipari fejlődése erősen korlátozott maradt. Ennek ellensúlyozására a 20. század ötvenes, hatvanas és hetvenes éveiben többek között számos egykori mezővárosban felülröl irányított iparfejlesztés történt (Enyedi 1988), ennek ellenére e települések máig örzik sajátságos mezővárosias karakterüket (pl. Kapuvár, Pápa), a településkép teljes átformálódása csak ritkán történt meg (Várpalota).

A mezövárosi épített (és természeti) környezet meglévő értékeinek megóvásáról, ill. az újabb keletủ településképi problémákról az írás második részében részletesen szólunk.

\section{Eltérö településszerkezet-típusok és telekhasználat az Alföldön és a Dunántúlon}

Az egykori mezövárosaink magvát alkotó történeti településrészek organikusan kifejlődött, ún. nött alaprajzi képleteket mutatnak. Az alaprajz formái legtöbbször a terepalakulatokhoz idomulnak: az ösi utcák lágyan hajlanak vagy kusza szövetet alkotnak. Jól elkülöníthetők a később tervezett településrészektöl, amelyek alaprajzai jóval merevebbek, a derékszögü vonalzó nyomait viselik magukon. Nem szabad elfelejteni azonban, hogy a tervezett településszerkezetekbe sok spontán elem is bekerülhet és a nőtt alaprajzok részletein is felfedezhetünk tudatos, tervszerü megfontolásokat.

A falvak és városok alaprajzai közé nem húzható éles határ, de a városok szerkezete természetesen összetettebb. A kezdetben egyszerübb településszerkezet lassan többé-kevésbé elváltozott (pl. a mezögazdasági termelési módszerek fejlödésének hatására, részben utólagos városrendezési beavatkozások során), ill. jelentösen kiegészült újabb típusú telekosztásokkal. A város ezért több eltérỏ korú és morfológiájú településrészből áll, sőt a területfelhasználás dominanciája alapján is jellegzetes részekre osztható. Ennek ellenére a legtöbb városban az ösi településrészek árulkodnak a valamikori faluállapot alaprajzi képletéröl - különösen az egykori mezővárosokban.

A történeti településkutatók feladata a soktényezös településfejlödés leképezése idöben, térben. Kívánatos, hogy a kutatók szemlélete organikus (fejlödéstörténettudatos) legyen, a komplex humánökológiai és fizikai településszerkezeti rendszerezés-tipologizálás igényével - a vizsgálati szempontok, fogalmak keveredése nélkül. Nem helyes például, hogy eddig sokszor fogalmilag egybefolyt a település területi rendjének és utcarendszerének vizsgálata a telekforma és a beépítési módok vizsgálatával - ezeket inkább egymásra épülő rétegként célszerü felfogni, hiszen a településszerkezet más-más szintjét írják le. Máté Zsolt (1998) ezért településszerkezet analízisénél többféle, elkülönített osztályozási szempontot vezet be (7. ábra), ezeket röviden jellemezzük is. 
Somfai Attila : Kisalföldi és alföldi mezővárosok különbözősége, kisvárosi értékek védelme. Tér és Társadalom 16. évf. 2002/1. 59-98. p.

TÉT XVI. évf. 2002 - 1

Kisalföldi és alföldi mezövárosok ...

69

\section{7. ÁBRA}

Máté Zsolt javaslata a magyar falu többszempontú településszerkezeti osztályozására

(The Proposal of Máté Zsolt for a Multiphasic Settlement Structure Classification of the Hungarian Village)

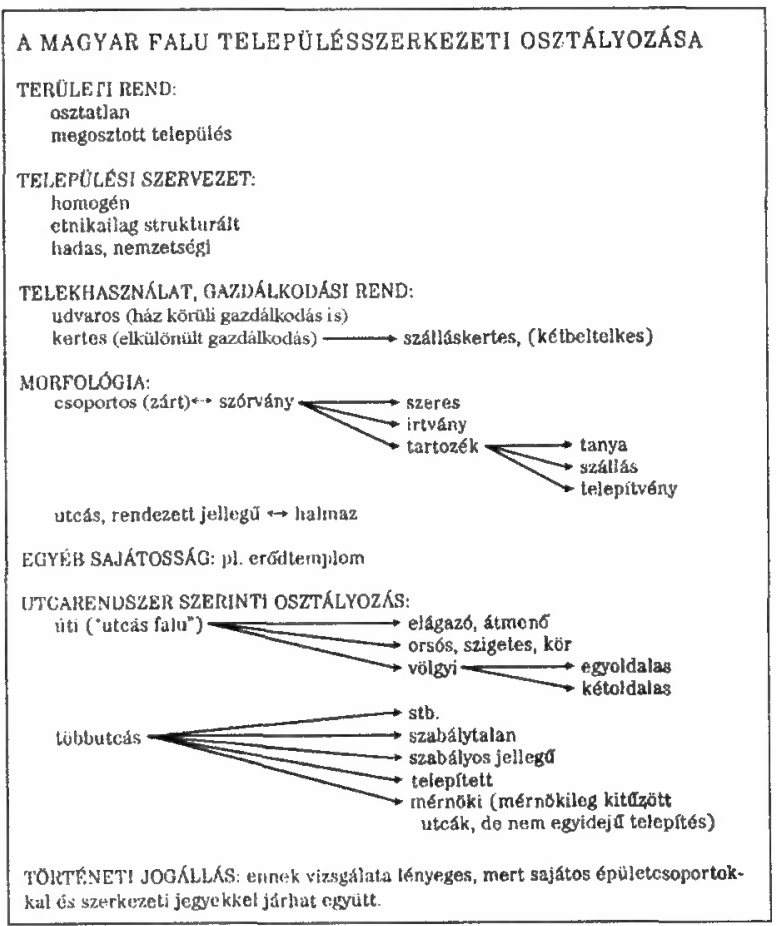

Forrás: Máté 1998.

A magyar agrártelepülés (pl. falu vagy mezőváros) fö területi rendje szerint lehet osztatlan vagy megosztott település. A megosztott település lehet például két telepủlésből összenőtt, sokáig „kétközpontú” település (pl. Mosonmagyaróvár), vagy település+szölöhegye (hegyközség), vagy település+besủrüsödő szórványtanyavilága. A településföldrajzban kialakultakkal ellentétben úgy véljük, hogy nem szerencsés ide sorolni a már csak történetileg létező kétbeltelkességel létrejött ,településosztottságot", mivel az inkább a telekhasználatból fakadó település-övezetesedés.

A településföldrajzban kialakult tágabb értelmủ morfológiai osztályozás szerint a magyarországi mezőgazdasági jellegủ telepủlések lehetnek magánosak, szórványosak vagy csoportosak (más néven zártak). Eszerint magános település például az alföldi tanya, amely az alföldi mezővárosias fejlődés „,mellékterméke”. A szórványtelepülés több magános településből, pl. tanyákból vagy szerekból rajzolódik ki, de még nem alkot a falvakéhoz hasonló beépítési sürüséget (érdekes, hogy a 11. századtól létező őrségi dombtetői „szer” nevû településrészek kialakulása nem rokon a 18. századi alföldi tanyákéval, hanem csupán a matyó ,had"-akkal, illetve a székely 
Somfai Attila : Kisalföldi és alföldi mezővárosok különbözősége, kisvárosi értékek védelme.

Tér és Társadalom 16. évf. 2002/1. 59-98. p.

településeken a nemzetségi rendet tükrözö „tíz"-ekkel). Csoportos (más néven zárt) települések a falvak, városok, így egykori mezövárosaink is. Felvetjük, hogy e besorolásban az önálló településnek tekintett tanyát helyesebb lenne településtartozéknak nevezni - figyelemmel a kialakulástörténetre (kihelyezett gazdasági egység).

A települési szervezet szerint megkülönböztethetünk homogén, etnikailag strukturált, illetve hadas strukturáltságú (ill. ezzel rokon nemzetségi strukturáltságú) települést.

A telekhasználat és gazdálkodási rend ösfajtái szerint megkülönböztethetünk a háztól elkülönülő (ún. kertes) vagy ház körül is zajló (ún. udvaros) gazdálkodást. A kertes gazdálkodásnál a házak sürün és gyakran kerítetlenül települtek egymás közelébe (állattartás, ill. földmüvelés csak a háztól elkülönült kertekben és a határban zajlik), az udvaros gazdálkodásnál a házak egymástól távol települtek (karámos állattartás, ill. földmüvelés a ház közvetlen közelében is megtalálható). Ez utóbbinál a nagyállattartó legeltetés természetesen nem folyhatott csak a ház körül, annak nagy helyigénye miatt. Számos kutató szerint a kertesnek nevezett gazdálkodás mutat vissza a nomád szilaj állattartás felé, azonban az egyértelmü kapcsolat még nem tekinthetö bizonyítottnak. A kora-középkori falvakban az udvaros gazdálkodás a laza soros jellegú településekhez kötődik, a kertes gazdálkodás pedig föként halmaztelepülésekhez (háztól elkülönülö szilaj-félszilaj állattartás dominanciája). A középkori halmaztelepülésekben már az udvaros gazdálkodás is tért hódított (karámos állattartás, ill. földmüvelés), a földmüvelés általánossá válásával pedig az udvaros gazdálkodás végül felülkerekedett a kertessel szemben (lásd késöbb a történeti statisztikai számítás adatait).

A települési utcarendszer rajzolatát vizsgálva megállapíthatjuk, hogy egykori mezövárosaink - a legősibb településrészeik alapján - lehetnek halmaztelepülések, valamint utcára szervezett alaprajzi rendszerü települések. Az utcára szervezett alaprajzi rendszerü falvak lehetnek egyszerübb, ún. utcás (soros) falvak és összetettebb, azaz többutcás települések.

Az utcás (soros) falvakon belül elkülöníthetỏ típusok az úti falu (változatai az átmenö úti falu és az elágazó úti falu), az orsós utcájú falu (változatai a szigetes falu, ill. a körfalu), és a völgyi falu (amely a patakhoz viszonyítva települhet egyoldalasan vagy kétoldalasan).

A többutcássá fejlődött település lehet szabályos vagy szabálytalan szerkezetü (vagy ezek sajátságos keveréke). Többutcás település kialakulhatott organikus fejlődés eredményeként, létrejöhetett egyszeri telepítéssel (pl. a középkori telepítöbiztosok által létrehozott falvak, ill. a 17. század elején alapított hajdúvárosok) vagy létrejöhetett többidejü telepítéssel is.

A telekrendszert és a beépítést a kataszteri térképeken megvizsgálva a szalagtelkek rendszere legtöbbször még ma is felismerhetö, azonban a hagyományos oldalhatáros (másnéven fésüs) beépítés - föként a település centrumában - fázisonként fokozatosan zártsorúvá, sőt emeletessé fejlődött (8. ábra). A történeti településmaghoz „hozzáragasztott” újabb szerkezetủ településrészeket általában könnyen felismerhetjük a hagyományostól elérő utca-, telek- és beépítésformákról (,vonal- 
Somfai Attila : Kisalföldi és alföldi mezővárosok különbözősége, kisvárosi értékek védelme. Tér és Társadalom 16. évf. 2002/1. 59-98. p.

zóval" kiosztott utcák téglányforma telkekkel, ezeken szabadonálló, ikerházas, sorházas, láncházas stb. beépítésmódok, a házak elött kiszabályozott elökertsávval).

\section{8. ÁBRA}

A kapuvári Fö téri épületek elvi fejlödési fázisai, az oldalhatáros beépitéstöl a hézagosan zártsorú beépitésen át a századforduló emeletes zártsorú beépitéséig (Theoretical Evolutional Stages of the Buildings in the Main Square of Kapuvarr)

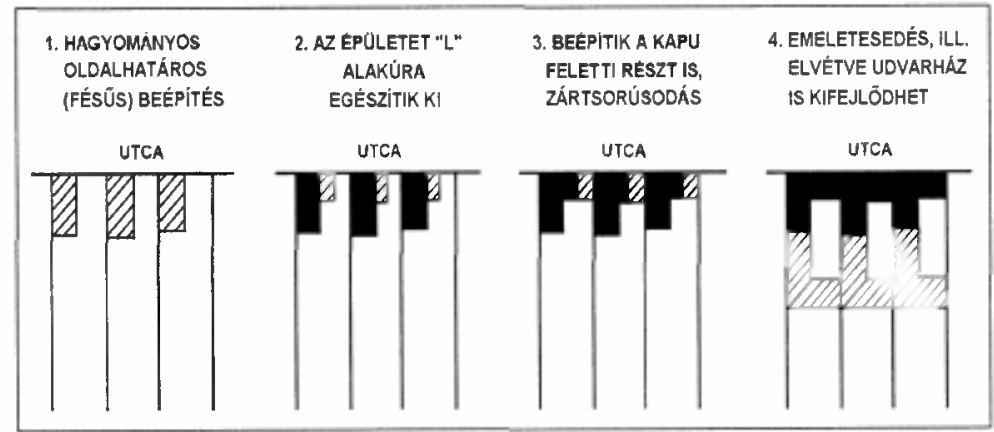

Forrás: Saját szerkesztẻs.

A bemutatott vázlatos osztályozások igazolják az elkülönített, következetes tipologizálás szükségességét a településszerkezetet felépítỏ különbözö szinteken - a településalaprajz egészének besorolásától haladva a telekbeépítési jellemzök azonosításáig (sőt a történeti épületalaprajzok fejlődése is legtöbbször jól tipologizálható).

A konkrét vizsgálatoknál az ismertetett fogalmi halmazok elemei természetesen összepárosíthatók a vizsgálat célja szerint. Jó példa erre a területi tendenciákat is megmutató történeti statisztikai vizsgálatok, amelyek igen hasznosak és jó lenne azokat minél széleskörübben alkalmazni. 1998-ban a VÁTI munkatársai az Alföldön 267 csoportos (más néven zárt) település eredetét igyekeztek kimutatni. Az utcarendszer és a telekhasználat fogalmainak párosításával kifejezve a mintában 44\% udvaros utcás, 27\% mérnökileg kitủzött (udvaros), 17\% udvaros halmaz, 7\% kertes halmaz és $5 \%$ telepített eredetủ falut találtak. Nem meglepö, hogy az alföldi mintában az utcás települések mellett jelentős a halmaztelepülések aránya $(17+7=27 \%)$, ugyanakkor elgondolkodtató, hogy az udvaros eredetú gazdálkodás ma már jóval nagyobb arányú $(44+17=61 \%)$ az egykor híres alföldi nagyállattartást elméletileg jobban elősegítő kertes gazdálkodásnál (7\%) (Máté 1998). A kertes gazdálkodás számértéke a Dunántúlon feltételezhetỏen elenyésző lenne, bár az ottani településeken is létezett egy-egy külvárosi majorkert (szérüskert, hóstát) az utcanevek tanúsága szerint. A történeti statisztikai számítások még számos újfajta eredményt hozhatnak a történeti településkutatásban (pl. a Máté Zsolt-féle fogalmi kategóriák többféleképpen párosíthatók). A halmazmủveleti számításokat nagyon megkönnyítheti az alapadatok folyamatban lévő országos térinformatikai feldolgozása, melynek segítségével az előfordulások tájegységenként eltérései is megjeleníthetők lesznek. 
Somfai Attila : Kisalföldi és alföldi mezővárosok különbözősége, kisvárosi értékek védelme.

Tér és Társadalom 16. évf. 2002/1. 59-98. p.

A Máté Zsolt-féle tiszta tipologizálással párhuzamosan életképesnek érzünk olyan következetlenebb, de épp emiatt mégis jól áttekinthető rendszereket is, mint pl. az ún. morfológiai falutípusok besorolásrendszere (9. ábra). A besorolásrendszer a „legjellemzőbb tulajdonságok" vezérfonalán halad, ezért sokszor a településszerkezet eltérő szintủ jellemzỏi formálnak ki egy jól elkülöníthető morfológiai típust. A következö morfológiai leírásokban az utcarendszer szerinti osztályozás szerint haladunk, de ehhez tájföldrajzi, gazdálkodástörténeti, mikrodomborzati, telekrendszeri és beépítési információkat is hozzáadunk.

\section{9. ÁBRA}

Néhány jellemzó magyar morfológiai falutípus

(Some Characteristic Hungarian Morphological Village Types)

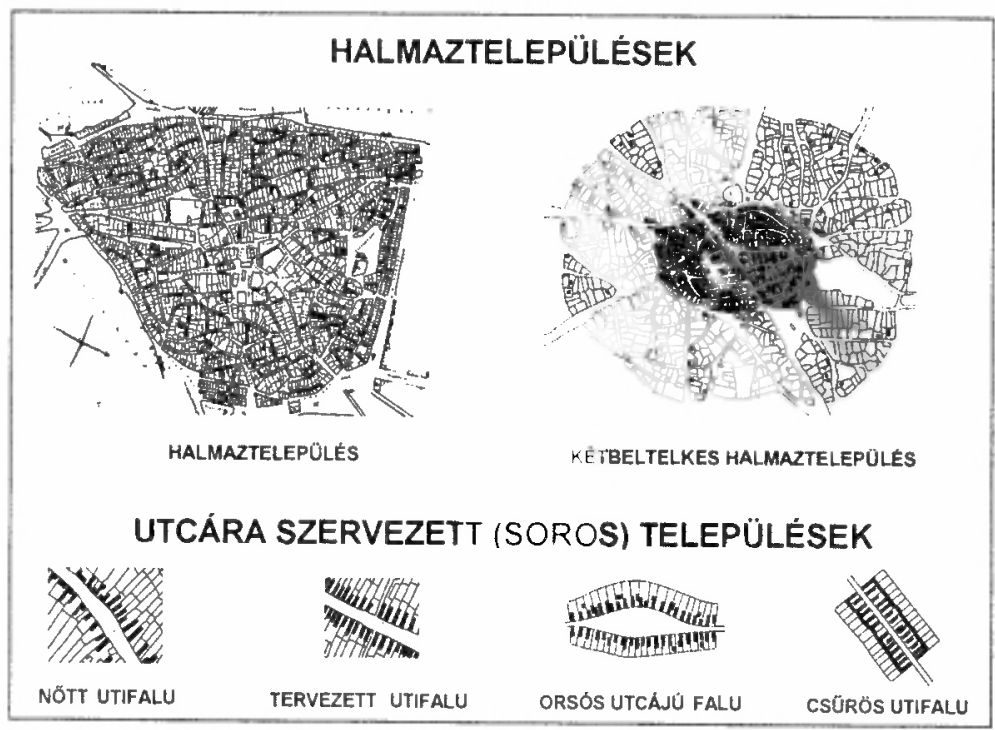

Forrás: Saját szerkesztés.

A halmaztelepülés az alföldi mezövárosokra jellemző, organikusan nőtt településforma. Utcahálózata, telkei, sőt az épületek elhelyezése is nélkülözi a geometriai szabályosságot. A látszólagos rendezetlenség azonban sajátos, környezetre érzékeny belső logikát mutat. Az épületek helykiválasztását leginkább a mikrokörnyezeti-mikrodomborzati adottságok határozták meg, azaz a legkisebb kellemetlen terepalakulatokat is elkerülték. A korai halmaztelepülésekben a sátrak, veremházak építését feltehetően nem elözte meg a mai értelemben vett utcák és lakótelkek kialakítása sem (ehelyett spontán kijárt járóvonalak és árkos-sövényes telekkijelölés volt jellemző, ez utóbbi is csak a települések egy részében). Az utcák elkülönítéselegalizálása és a telekhatárok rögzülése csak késöbb történt, így azok esetlegesek lettek (gyakoriak a hirtelen útirány-váltások, beszükülések vagy kiöblösödések (Tóth 2000). A telektömbök belsejében fekvő telkek egy részét sokáig csak idegen telkeken vagy zsákutcán át lehetett megközelíteni, ez az egyes telektömbök lakóinak (használóinak) közös származására, ill. a közös telek későbbi több részre osztá- 
Somfai Attila : Kisalföldi és alföldi mezővárosok különbözősége, kisvárosi értékek védelme. Tér és Társadalom 16. évf. 2002/1. 59-98. p.

sára utalhat (Mendöl 1932). Az utcák rajzolata alapján megkülönböztetett alföldi altípusok a sugaras halmaz (föbb útjai központi térre futnak össze) és a rostos halmaz (föbb útjai nagyjából párhuzamosak, ill. egymásra merőlegesek és szabálytalan négyszög alakú negyedeket zárnak közre). Ismert még a kusza halmaz is, ez azonban nem az Alföldre, hanem Erdélyre jellemzö (patak menti szórványtelepülések besủrüsöđésekor jött létre a központ nélküli kusza utcahálózat).

Az Alföldre jellemzö kétbeltelkes település a halmaztelepulés speciális történeti változata. A kutatók egy részének feltételezése szerint a honfoglalás kori magyarság külterjes, félnomád állattartás téli szállására vezethetỏ vissza. Eszerint a lakósátrak kisebb területủ övezetét a szabadban tartott állatok nagyobb területü övezete vette természetszerúleg körül (vagy nagyritkán csak csoport, ill. sor formájában különült el). Idövel a sátrakat szabadon álló és körülkerítetlen házak, az állatok szálláshelyeit pedig körülkerített ólaskertek váltották fel (Tóth 2000). Később az ún. pajtás- vagy csüröskertek már átmeneti típust képeztek a nyugatias (európai, dunántúli) külvárosi majorkertek (hóstátok) és az alföldi ólaskertek között (Láng 1986). A 19. századi ármentesítéseket követően a szántóföldi múvelés általánossá válásával a belső magban lévő házakat is körülkerítették, ha esetleg ezt korábban még nem tették meg. Később már a nagyméretü csüröskertekben is megjelentek a lakóházak. A telekstruktúra azonban még sokáig árulkodik a múltról, kimutathatók a két övezet közötti különbségek. A telkek mérete a településközpontban ma is kisebb (300-500 $\mathrm{m}^{2}$-es), míg a település szélén jóval nagyobbnak megmaradt telkek is lehetnek $\left(2000-4000 \mathrm{~m}^{2}\right.$ vagy akár $6000 \mathrm{~m}^{2}$ ) (Perényi 1972).

Az utcás (soros) falvak alaptípusai a különböző féle útifalvak - korai állapotukban szalagtelkes és fésüs beépítésü falutípusok. Ezek a dunántúli falvak és mezővárosok ösi településrészeinek elemzésekor gyakran visszaköszönnek, de nem ritkák alföldi falvaknál sem. A későbbi többutcás falvak az egyszerủbb típusok organikus továbbfejlődésével vagy pedig telepítỏ akció(k) eredményeképpen jöttek létre.

A nőtt útifalu általában tudatos szabályozás nélkül alakult ki (változatai az átmenő úti falu és az elágazó úti falu). Lágy hajlatokkal követi a terep alakulatait az utca, amelyre közel merölegesen keskeny és hosszú szalagtelkek sorolódnak. Az utca és a telkek is enyhén változó szélességủek. A telkek felhasználását alárendelték a mezögazdaság követelményeinek: a lakópuuletek elhelyezésén kívül biztosította az istállóban, ill. ólakban tartott állatok elhelyezését a ház közelében, a mezőgazdasági járművek és takarmányok tárolását, a telkek jó részén ezen felül veteményes kert is volt. A telek szélfújta oldalára épített, utcavonalon álló lakóház mellett a viszonylag keskeny telek (13-16 méter) másik felén elég széles sáv maradt ahhoz, hogy a mezőgazdasági jármüvek a telek mélyén lévő tárolóterületet elérhessék.

Az orsós utcájú falu is legtöbbször szalagtelkes, de az utca a falu közepén kiszélesedik (ez a tér orsóforma helyett nagyritkán kör, ekkor körfaluról beszélünk). A méretes, de zártsága folytán jố ellenörizhetö piactér ad helyet a templomnak is, később más közintézmények is a térre vagy annak szélére, az egyre rangosabb épuletekböl álló térfalba települnek. Az orsó alakú tér meg is telhet az utólagos beépítéssel, ekkor szigetes falu jön létre. 
Somfai Attila : Kisalföldi és alföldi mezővárosok különbözősége, kisvárosi értékek védelme.

Tér és Társadalom 16. évf. 2002/1. 59-98. p.

74

A csủrös útifalu a késỏ középkorban betelepült németek speciális településformája, az útifalunak egy beépítési mód szerinti változata. A csürös beépítés a szalagtelken hosszanti irányban sorolt melléképületek keresztbe állításával jött létre. Ez föleg védelmi célokat szolgált, ill. szük völgyek esetén a lakóház mögött meredeken emelkedő terep sem tette lehetővé a melléképületek telekhatár melletti hosszanti sorolását.

A völgyi faluban a szalagtelkek a kígyózó vízfolyásra merőlegesen sorakoznak a patak egyik vagy mindkét oldalán, a patakvölgy domborzati adottságainak függvényében (egyoldalas vagy kétoldalas völgyi falu).

A szalagtelkes útifalu speciális esete a sorfalu, amelynek hosszú telkei az utcától egészen a helység igazgatási határáig érnek. Nemcsak a házat, gazdasági udvart és házikertet foglalják magukba, hanem egyben a szántót, legelöt és az erdőt is. A történelmi Magyarországon elsősorban a Szepességben jött létre a sorfalu hegyvidéki változata, az ún. erdőtelkes falu.

A tervezett útifalu szintén szalagtelkes rendszerü, de érezhetően szabályosabb alaprajzú, tehát az utca és a telkek szélessége nemigen változik. A német betelepítésekre jellemzö. Védelmi okokból gyakran nem az országúton, hanem abból leágazva, zsákszerüen települt.

A többutcás falvak a nőtt falutípusok továbbfejlödésével, vagy telepítés(ek) során alakultak ki. Terjedelmi okokból mellőzzük az ezekben megfigyelhető sajátos utcaés telekalakítási részjelenségek leírását.

A történeti térképeken még tetten érhetö késö-középkori magyar településszerkezeti sajátosságok és települési kultúra jobb megértéséhez kívánatos lenne ismerni annak középkori és honfoglalás kori előzményeit, sőt még a honfoglalás elötti települési szokásokat is. A tudomány - elegendö adat hiányában - eddig bizonytalan visszakövetkeztetésekkel, számos eltérő vélekedéssel szolgálhatott.

Az egyik legvitatottabb kérdés, hogy a Kárpát-medencében vajon a soros jellegü vagy a (kétbeltelkes) halmazos jellegü településelrendezés tekinthető ősibbnek? Az eddigi vélekedéseket - csak vázlatosan és lényegre törően - idörendi csokorba szedjük:

1) Az egyik korábbi vélekedés szerint a (kétbeltelkes) halmaz jellegü település már a honfoglalás előtt is létezett az avaroknál (László 1944), a honfoglalás után pedig ez a településforma általánosnak tekinthető a Kárpát-medencében (Györffy 1943; Mendöl 1963). A soros jellegü települések először csupán a kora-középkorban jelentek meg a királyi kézbe került gyepü-, ill. nemzetségválasztó területeken, föként idegen telepesek hatására (Mendöl 1963).

2) A másik, sokáig általánosan osztott vélemény szerint a honfoglalás elött a laza soros jellegü települések domináltak a Kárpát-medencében (Györffy 1943; Perényi 1972). A honfoglalás után azonban a (kétbeltelkes) halmaz jelegü települések váltak dominánssá, föként a magyarok állattartó életmódja miatt. A soros jellegü településtípusok csupán később szaporodtak el a Kárpátmedencében, ott is elsősorban a nagyállattartásra kevéssé alkalmas domb- és 
Somfai Attila : Kisalföldi és alföldi mezővárosok különbözősége, kisvárosi értékek védelme. Tér és Társadalom 16. évf. 2002/1. 59-98. p.

hegyvidékeken, ehhez jelentősen hozzájárultak az egész országterületet érintő telepítések is.

3) Az autópálya- és gátrégészet uij ásatásaira (és a Szent László előtti temetőknek a település tükörképét hủen leképezö sírkiosztására) alapozott képlékeny vélemény szerint a laza soros jellegü és a laza (vagy éppen sürü!) halmazos jellegü települések a honfoglalás elött és a honfoglalás után is egyidejủleg voltak már jelen (Máté 1998). A (kétbeltelkes) halmaz jellegủ települések számaránya nőhetett a honfoglalás után (föként az Alföldön), hiszen a településszerkezet jelentősen életmódfüggő. A halmaztelepülések mellett azonban a laza soros jellegü, majd az azokból kifejlődő soros jellegủ típusok mindvégig jelen voltak, bár területileg és időben is egyenetlen eloszlásban. A soros települések elsősorban a nagyállattartásra kevéssé alkalmas, topográfiailag determináltabb domb- és hegyvidéken terjedtek el, ehhez jelentősen hozzájárultak az egész országterületet érintô telepítések is. A halmaztelepülésekhez képest védtelenebb soros jellegü települések a tatár- és törökdúlások során különösen az $\mathrm{Al}$ föld síkján ritkultak meg, miközben a halmazszerkezetü mezövárosok felduzzadtak. Az Alföldön a soros települések csupán a hosszú török uralom elmúltával hódítottak ismét tért, amit már a lassú életmódváltozás is elősegített.

A másik legvitatottabb kérdés, hogy a magyar történeti agrártelepüléseken, azaz a mezővárosokban és falvakban kimutatott településszerkezeti sajátosságokat vissza tudjuk-e vezetni egészen a honfoglalás korig, kimutatható-e a genetikus folytonosság? Tény, hogy a soros települések (legtöbbször szalagtelkes útifalvak) nagyon messze állnak a honfoglalás kori laza soros jellegü (másnéven füzér) településelrendezéstôl. Ugyanígy a (kétbeltelkes) halmaztelepülések is nagyon messze állnak a honfoglalás kori laza (vagy éppen sürü!) halmazos jellegü településelrendezéstöl (Novák 1986; Beluszky 1999). Nehézség, hogy a kétbeltelkes halmaztelepülés csupán a 16. századtól igazolható hitelesen, kevés a honfoglalás kori régészeti adat, miközben tetemes az áthidalandó időbeli, morfológiai, ill. a társadalmigazdálkodási viszonyokbeli „távolság”. Az eddigi elméletek főként a (kétbeltelkes) halmaztelepülések genetikai folytonosságát próbálták igazolni, azok korábbi nimbusza miatt (sokan magyar ösformának vélték, de már számos külföldi kutató munkájában felfedezhetjük a magyar szálláskertes települések európai megfelelőit) (Hofer 1980; Bárth 1996). Az autópálya- és gátrégészet új ásatásait is figyelembe vevő igen képlékeny vélemény szerint a kétbeltelkes halmaztelepülés és a honfoglalás kori téli szállás genetikus rokonsága - korábbi vélekedésekkel ellentétben - még nem tekinthetö bizonyítottnak, de további régészeti eredmények alapján lehet, hogy mégis bebizonyítható lesz. (A téli szállásról magyarázatként megjegyezzük, hogy az a téli és nyári szállást váltó állattartó életmódhoz kötődött).

A genetikai rokonság bebizonyításához talán Máté Zsolt következtetései visznek közelebb minket. Míg Györffy István úttörỏ módon a kirgizek téli szállásából (ill. a honfoglaló magyarokéval rokonítható életmódból) kiindulva próbált eljutni az alföldi ólaskertes településekig, addig Máté Zsolt fordított gondolatmenettel próbálkozott. A régi és új ásatások által feltárt településelrendezési képletekböl kíván 
Somfai Attila : Kisalföldi és alföldi mezővárosok különbözősége, kisvárosi értékek védelme.

Tér és Társadalom 16. évf. 2002/1. 59-98. p.

TÉT XVI. évf. 2002

következtetni a honfoglalók életmódjára, majd ezt rokonítani a kétbeltelkes (más néven szálláskertes, ólaskertes) alföldi halmaztelepülések lakóinak életmódjával.

Az egyszerủ népek laza településelrendezési képletei főként a gazdálkodási módokkal (pl. állattenyésztéssel, kezdetleges földmüveléssel) és a környezeti adottságokkal hozhatók összefüggésbe - érvényes ez a honfoglalás kori magyar településekre is. Az ásatások valóban igazolták a domborzati-mikrodomborzati adottságok érzékeny figyelembevételét. Igazolódni látszik az is, hogy már a honfoglaláskor is két ősi gazdálkodási forma létezett (azaz a sürün települt hajlékoktól elkülönülö vagy pedig a ritkábban települt hajlékok körül is zajló), ami pedig a jóval későbbi mezővárosokban és falvakban kimutatott „kertes” és „,udvaros” gazdálkodási elvvel analóg. A honfoglalás kori halmazos jelegü településekben ugyanis a lakósátrak, ill. veremházak igen sürủn települtek, távolságuk csupán 2,5-3 m (ez a háztól elkülönülő szilaj állattartásra utal). Ezzel szemben a soros jellegủ településeken a lakósátrak, ill. veremházak lazán települtek, távolságuk akár 50-100 m is lehet (állattartás, ill. földmúvelés a ház körül is megtalálható). A hajlékoknak ugyanilyen távoli elrendezése figyelhető meg már az időben valamivel későbbi, halmazos jellegü települések egy részén is (már nem csak háztól elkülönült szilajállattartás, hanem állattartás, ill. földmüvelés a ház körül is).

A „kertes” és ,udvaros” jellegü gazdálkodási formák megléte, illetve a hajléképítés többfélesége stb. arra enged következtetni, hogy a 10-12. században az eltérỏ fejlettségi szinteket képviselö életmódok egymásmellettisége valószínüsíthető, azaz a népességnek egyidejűleg lehetett még ősi nomadizáló (azaz vándorló, legelőváltó) rétege, emellett szállásváltó állattartó rétege, de már talajváltó-mozgófalvas rétege, sőt akár letelepült rétege is (Máté 1998).

A kora-középkori településfejlődési folyamatok két lényegesebb történése lehetett a szállásváltó életmód téli szállásainak fokozatos állandósulása, illetve a laza soros jellegü településeknek a soros útifalvakká alakulása, szalagtelek-rendszerük kifejlödésével. Az Alföldön a honfoglalás korában a sátrakból (később veremházakból) álló szállást a szabadban (később kezdetleges karámokban) teleltetett állatok nagy területigényü övezete vette körül. A nyári időszakkal ellentétben a téli időszak kevéssé tette indokolttá a helyváltoztatást (pl. legelőváltást vagy árvizek-belvizek elöl való elhúzódást), így a téli szállás fokozatosan helyhez rögzült és felerősödtek közvetlen körülötte az árkos-sövényes szálláskert-elhatárolási folyamatok is. $\mathrm{Az} \mathrm{Al}$ földdel szemben a Dunántúl (és a többi domb- és hegyvidékek) a nagyméretủ állatcsordák terelgetésére-legeltetésére kevésbé voltak alkalmasak, topográfiai viszonyaik és sürübb növényzetük folytán. Ezeken a területeken az állattartás mellett hamarabb tért hódított a földmüvelés is. A soros jellegü települések (köztük a nagy számú irtásfalvak, ill. erdötelkes falvak) telkeinek osztódásával, sürüsödésével jöhettek létre a későbbi soros szalagtelkes útifalvak. A 12-14. században a földesurak az erdős, hegyi tájakon gyakran vállalkozókra (soltészekre) bízták a falutelepítést, ami már szabályos telekkimérést, rendezettséget eredményezett.

A hazai történeti településállománynak a középkortól napjainkig tartó fejlődésére vonatkozó eddigi elméleti kutatások már jóval biztosabb eredményre jutottak a 
Somfai Attila : Kisalföldi és alföldi mezővárosok különbözősége, kisvárosi értékek védelme. Tér és Társadalom 16. évf. 2002/1. 59-98. p.

honfoglalás korára vonatkozó kutatásoknál. Ezeket összefoglalva megfogalmazhatjuk, hogy a hazai települések sokféleségét alapvetően a földrajzi viszonyok és a gazdálkodási módok határozták meg, és emellett a településkép formálódásában nagy szerepe volt a történelemnek, a település saját történelmének is (Bárth 1996). A földrajzi tényezök különbözösége mellett tehát a Dunántúlra, ill. az Alföldre jellemző eltérő településfejlődés számos más okra is visszavezethető. Az egyik ok, hogy a középkorban eltértek a jellemzỏ gazdálkodási módok (a Dunántúlra fejlett földmủvelö kultúra is jellemző volt, ellenben az Alföldön elöforduló kétbeltelkes településeken sokáig a nagy tartásterület-igényü állattartás dominált). A másik a védelmi szempont lehetett (jobban védhető, köralakhoz közeli halmaztelepülések az Alföldön). A harmadik ok az eltérő társadalomszerkezet (a Dunántúlon az individualitás, az Alföldön a török hódítókkal szemben összetartóbb közösségi társadalom). A Dunántúlra hatással voltak még a szomszédos országok, ill. az onnan áttelepített lakók által „,behozott” települési hagyományok is.

Ha a különböző földrajzi tényezőket közelebbről megvizsgáljuk, megállapíthatjuk, hogy az Alföld, ill. a Dunántúl eltérỏ településfejlődésére leginkább a topográfiai viszonyok voltak hatással. Ha az ország domborzati viszonyait, valamint a soros és a halmazos fötípusra jellemzỏ elterjedési területeket összevetjük, akkor megállapíthatjuk, hogy a soros felépítésủ települések többsége az ország domb- és hegyvidékein jött létre (azaz a Dunántúlon és az Északi-középhegységben), míg az Alföld síkvidékein kétbeltelkes halmaztelepülések is kialakultak. Az országrészenként eltérő domborzati viszonyok a települések belterületén is visszaköszönnek. Amíg az alföldi településeken az átlagos domborzati magasságkülönbség nagyságrendje csupán fél méter körüli, addig ez a Kisalföldön 2-5 méter, a dunántúli dombvidéki településeken 5-10 méter, a hegyvidéki településeken pedig akár 30-50 méter is lehet. Ezek a nagyságrendi különbségek is hozzájárultak ahhoz, hogy az Alföldön a tereptỏl függetlenebb, több szempontból is kedvezö, ,ideális körformához" közeli nagy települések is zavartalanul létrejöhettek, szemben a Dunántúl és az Északi-középhegység topográfiailag erősebben determinált településeivel (Somfai 2001b).

Figyelemre méltó, hogy mind a soros, mind a halmazos jelleget mutató - és szintvonalakkal is ellátott - középkori faluásatási helyszínrajzok (Móric, Sarvaly) a letelepedés domborzati (sőt mikrodomborzati) érzékenységéröl árulkodnak (Máté 1999a). Az ország soros felépítésủ (utcás) településtípusai rendkívül gyakran domborzati okokra vezethetők vissza (Marosi-Szilárd 1974), és előfordulásuk különösen gyakori a Dunántúl szabdalt, erősebb reliefenergiájú felszínein. Emiatt az erösen tagolt felszín miatt a Dunántúlon a településállomány fejlődése sokkal bonyolultabb, mint az ország más területein, és a Dunántúlon belül tájanként is más és más (Boros 1957). Az alföldi települések morfológiáját csak kevésbé befolyásolták az ottani enyhébb felszínformák. Ez alól azonban kivételt képeznek például a folyókat kísérỏ vízmentes folyóteraszok (Máté 1989).

Véleményünk szerint a számos útifalu típus - mint ahogy a kétbeltelkes halmaz is - a nevében hordozza az egyik legjellemzỏbb vizsgálandó tulajdonságát, azaz a 
távolsági utakhoz való viszonyát. Úgy véljük, hogy a Dunántúlon (és az ország többi domb és hegyvidékén) a markánsabb topográfiai viszonyok az útvonalak kiválasztódását-lerögzưlését elỏbb eredményezték, mint az Alföldön. Ez is közrejátszhatott abban, hogy a Dunántúlra ,tudatosan” az utak mentén szervezödö településtípusok jellemzők. Ezzel szemben az Alföld finom domborzati eltérései sokkal kevésbé lerögzült úthasználatot eredményeztek (sőt a vízjárta hónapokban szinte „úttalan" úthasználatot). Ezért a feltehetỏen lassabban helyhez rögzült alföldi halmaztelepülések szerkezetét nem az utak határozták meg, hanem a vízjárta síkból épphogy kiemelkedő szárazabb halmokon való „spontán” összegyülekezés, azaz szinte irányfüggetlen öszehalmozódás-összetömörülés, ami nem ütközött markáns topográfiai akadályba. Később az Alföldön is határozottabb úthálózat fejlödött ki, így az útifalu típusok is jobban elterjedhettek, amit már a gazdálkodási módok fokozatos megváltozása is segített.

Az eddigi kutatások többségében az alföldi történeti települések szerkezetét a dunántúli településekéhez képest behatóbban vizsgálták, mivel a kétbeltelkes halmaztelepüléseket sokáig sajátságosan magyar jelenségnek tartották. Mindez az eddig szerényebb mértékben kutatott dunántúli soros települések alaprajzi vizsgálatának fokozott szükségességére hívja fel a figyelmet, amelyben a gazdálkodási-történelmi összefüggések és idegen települési hatások stb. mellett a geomorfológiai adottságok településformáló hatását is részletesen elemezni indokolt (Somfai 2001a), nem elfedve a településhez vezető ősi útvonalakat sem. Legjelentősebb az elmaradás az észak-dunántúli településeknél, míg a Dél-Dunántúlon a helyzet jóval kedvezöbb a pécsi földrajzkutatóknak köszönhetöen.

\section{Az alföldi mezövárosok fejlödéséröl röviden, kiragadott példákkal}

Az Alföldön a 13. században a tatárok népirtása következményeként az apróbb települések elpusztultak vagy életképtelenné váltak. Népességük a jobb helyzeti energiával rendelkezö, központibb fekvésủ településekbe vándorolt, így az elpusztult falvak határa is föként a mezövárosok területét növelte. Az így kialakuló tágas határ a mezővárosias fejlődés fő alkotó eleme: az agrárium többlettermelése teremtette meg a városiasodás anyagi feltételeit (10-11. ábra). A megnövekedett határt föként a külterjes állattartás szolgálatában - a jobbágytelkinél kedvezöbb ún. kertes rendszerben használták, a nyomáskényszer vagy az újraosztás kényszere nélkül, az egyéni gazdálkođás igényeinek megfelelően. A lakosság a település központjába húzódott be, melynek védelmi szerepét kialakították, onnan irányították a tágas határon lévő gazdaságukat. Nem állt jogukban kőfallal körbevenni a várost, ám árokrendszerrel, sövénnyel kialakíthatták védelmi rendszerüket (Novák 1989). Az alföldi mezővárosi fejlödés sajátossága, hogy a török veszély elmúltával, majd a gabonatermelés 18. századi térnyerésével a mezövárosok és óriásfalvak népfeleslege fokozatosan szétömlött a puszta határokon, és a 19. század derekára fokozatosan kialakult a tanyavilág (Mendöl 1932). 
Somfai Attila : Kisalföldi és alföldi mezővárosok különbözősége, kisvárosi értékek védelme. Tér és Társadalom 16. évf. 2002/1. 59-98. p.

TÉT XVI. évf. 2002 — 1

Kisalföldi és alföldi mezövárosok ...

10. ÁBRA

Hajdúböszörmény a 18. század derekán, sugaras halmaztelepülés (Hajdúböszörmény in the Middle of the Eighteenth Century, Radial Cluster-type Settlement)

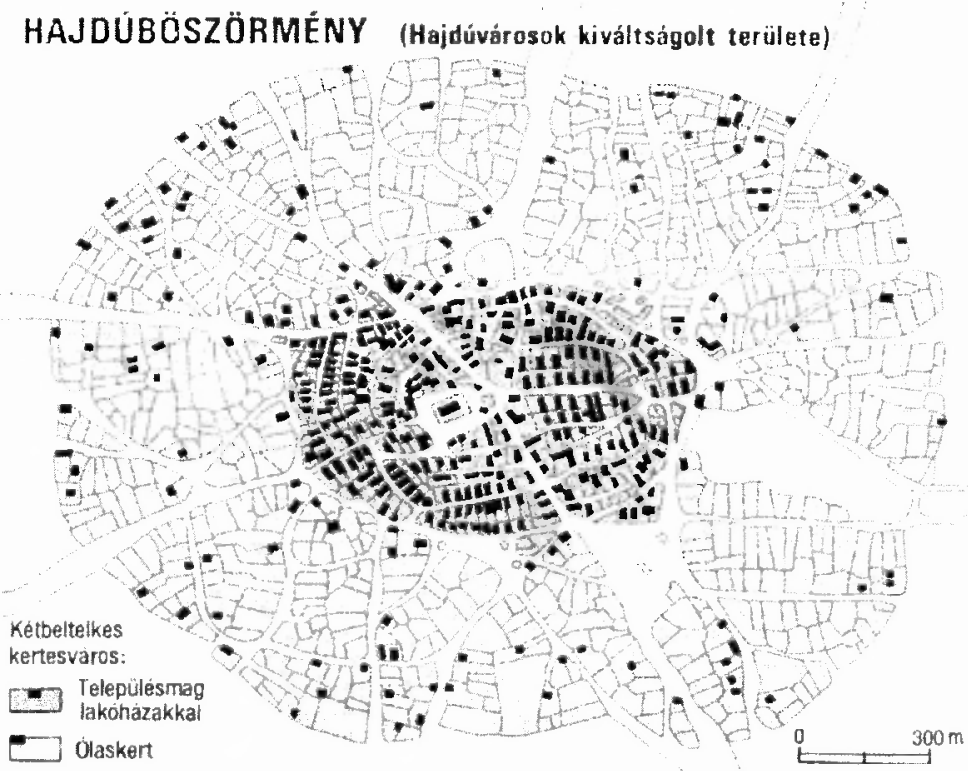

Forrás: Papp-Váry 1991.

\section{1. ÁBRA}

Hajdúböszörmény tágas határa a 18. században

(The Spacious Boundary of Hajdúböszörmény in the Eighteenth Century)

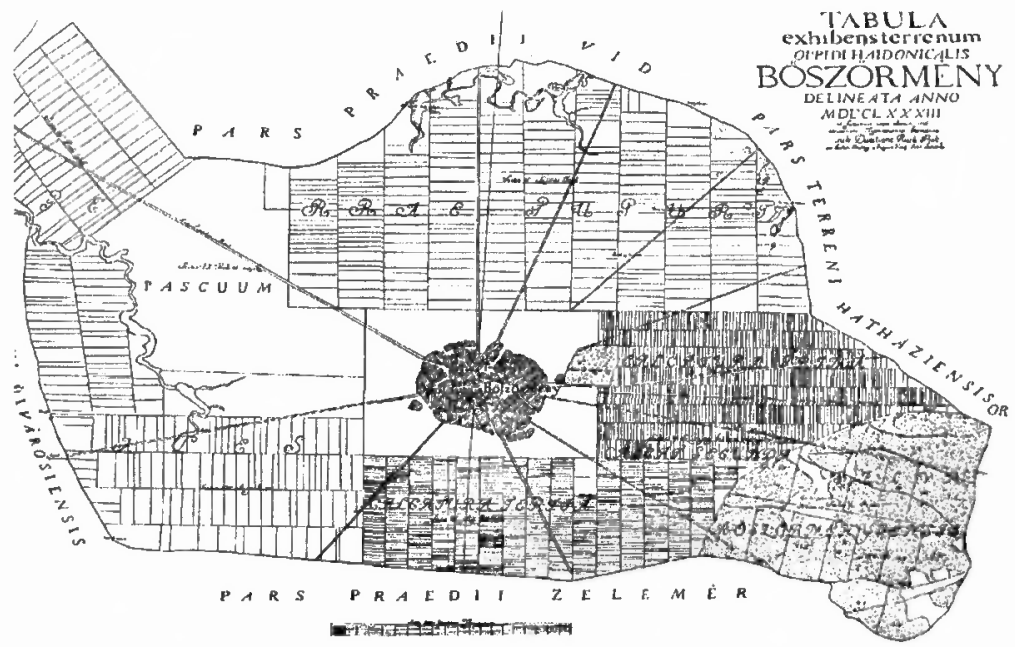

Forrás: Hofer 1960. 
Somfai Attila : Kisalföldi és alföldi mezővárosok különbözősége, kisvárosi értékek védelme.

Tér és Társadalom 16. évf. 2002/1. 59-98. p.

Cegléden és Nagykörösön az Alföldre jellemző kétbeltelküség alakult ki (az elkülönülő akolkertes övezetben még tiltották is az ottlakást). Kivétel Kecskemét, ahol nem alakult ki kétbeltelküség, funkcionális térbeli elkülönülés nem jött létre, ugyanis a lakóház és a gazdasági udvar egységet alkotott a halmazos szerkezetủ belsőségben. Szükség esetén a belsőségben felépített istállót lakóházzá is átépíthették.

A felszíni adottságok településformáló hatása az Alföld „tengersík vidékein” is jelen van - bár a dunántúliaknál kisebb intenzitással és csak a települések egy részénél. Az alföldi települések domborzatára már a harmincas években Győrffy István is felhívta a figyelmet. Cegléden és Nagykőrösön a kétbeltelkűség kialakulását a terepadottságok is elösegítették: a kissé magasabban fekvő részre települtek a lakóházak, a védő árokrendszeren túli laposabb peremrészeken pedig az akolkertek, szérüskertek létesültek. A dél-alföldi Duna-völgy egykori mezövárosai - hasonlóan a kisalföldi Rajkához, Hédervárhoz - az árvízmentes peremek ártérre néző leszakadásait, ill. az ártér kisebb kiemelkedéseit, folyóteraszait „ülik meg” (pl. Dunavecse, Szalkszentmárton, Hajós), de védtelen ártéri fekvésủ településeket is találunk, mint pl. Dunapatajt (Iván 1994).

Az Alföldön is találunk sok utcára szervezett alaprajzú települést. Az ún. utcás (soros) típusokhoz tartoznak a leggyakrabban völgyekben kialakuló egyutcás, valamint az ármentes kiemelkedéseken kialakuló többutcás települések (mint pl. Adony). A települések egy részénél a mérnöki telepítés is jellemző (pl. Hajós „sakktábla" utcarendszerü újabb részei).

\section{A kisalföldi mezövárosok fejlödése és néhány példája}

A Kisalföld jelentősebb települései kelta, ill. római alapításúak. Városait, falvait késöbb avarok lakták, öket a morvák igázták le. A magyarok 900 körül szállták meg e területeket. A 13. századtól fogva több ütemben németek telepedtek le, a török veszély elől pedig szlavóniai és horvátországi menekülteknek adott új hazát e vidék.

A Kisalföldnek a mai Magyarországra eső területén 1767-ben számos mezővárost találunk, így többek között a Sopron vármegyei Kapuvárt, Csornát, Fertőrákost, Mihályit, Szilt és Szanyt, Győr vármegyében Szentmártont, Komárom vármegyében Tatát és Tóvárost, Veszprém vármegyében Marcaltöt, Pápát, Tüskevárt és Devecsert (12. ábra).

1841-re újabb kisalföldi települések nyerték el a mezővárosi rangot (Fényes 1841), így Sopron vármegyében a Fertö menti Hegykö, a Csorna melletti Egyed, Györ vármegyében Hédervár, Moson vármegyében Lébény és Mosonszentjános, Komárom vármegyében Kisbér és Ószőny, Veszprém vármegyében pedig Somlószőlős.

A kisalföldi mezővárosok településalaprajzának korai állapota néha alig ismerhető fel. Ennek okai lehetnek a későbbi településbővítések, helyenként a korábbi településszerkezet rendezése-megváltoztatása, de akár a külső térszerkezet átalakulásának hatására történt belsö településszerkezeti átrendeződés is. 
Somfai Attila : Kisalföldi és alföldi mezővárosok különbözősége, kisvárosi értékek védelme. Tér és Társadalom 16. évf. 2002/1. 59-98. p.

TÉT XVI. évf. 2002 - 1

Kisalföldi és alföldi mezövárosok ...

81

A kisalföldi mezővárosok legösibb településrészeinek szerkezeti felépítése sokféle lehet. Legtöbb az eredendően egyutcás település (Fertörákos, Mihályi, Halászi), a többutcásak között nem ritkák az árvízmentes vonulatokra települö, több „,szer”-böl álló ún. szigetközi típusú nőtt települések (pl. Hédervár). Egyedi, kétpólusú településszerkezet jellemzi Mosonmagyaróvárt.

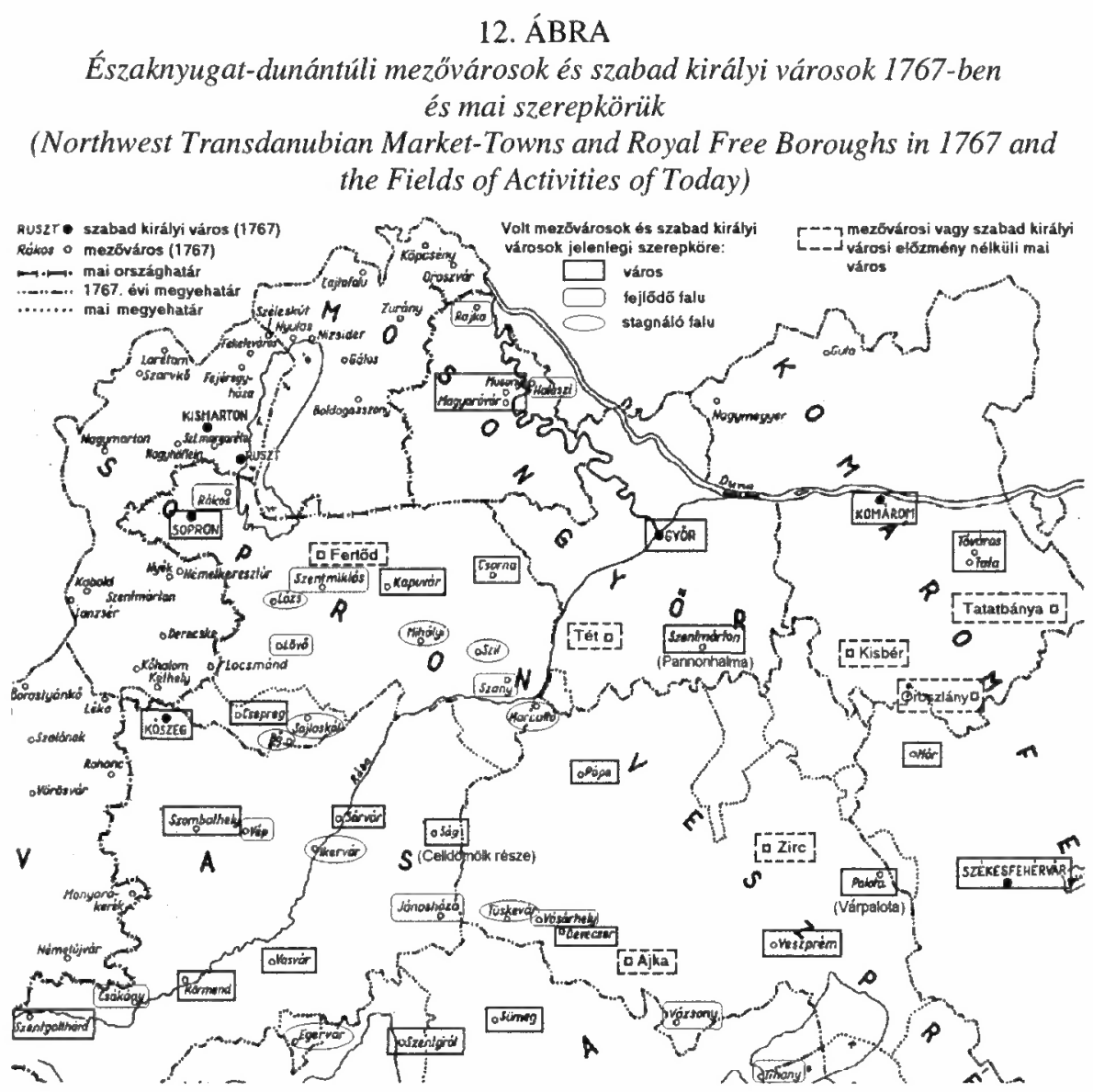

Forrás: Felhő 1970 alapján saját szerkesztés.

Míg a legtöbb alföldi mezöváros halmazos alaprajzán a településmagot a sürütelkes lakózóna, ill. a sugarasan összefutó utcák egyértelmủen kijelölik, addig a fóként utcás felépítésủ kisalföldi mezővárosok településmagja valamivel széthúzottabb. A településmag egy kiemelt pontján sok mezővárosban megtaláljuk a feudális (világi vagy egyházi) hatalom építményeit, amelyek általában a topográfiailag legelőnyösebb helyre igyekeztek települni. E nevezetes építmények elött gyakran több út is találkozik (pl. Kapuvárott, Pápán). Ha a település életében világi és egyházi irányítás egyaránt domináns volt, akkor e kettősség gyakran a településszerkezetböl is leolvasható (pl. Csornán). 
A nyugatias (európai, dunántúli) városfejlödésre jellemzö, hogy a feudális hatalom majorterületeivel közvetlen kapcsolatban kívánt maradni, így a hatalmi központ (a településmagot képező vár, földesúri rezidencia, kolostor, monostor) közvetlen közelében nemritkán évszázadokon át elkülönülő területet, ún. belső majort is felfedezhetünk (pl. Kapuvárott, Csornán). E területeken magasabb technikájú mezőgazdasági termelés folyt, ezért találjuk meg azokat a fallal védett településközpontokban is (pl. Pápán). Winkler Gábor szerint e „barát-dúlók” Európa-szerte csak a késői 19. századtól épültek be, így sokszor az egyik legfontosabb, még rendelkezésre álló potenciális „központképzö” rendeltetést töltötték be a legújabbkori városfejlesztésben (Winkler 1998).

A dunántúli településeknél a korai településállapot kialakulásának okfeltárásában a történeti térképek mellett a településtörténet elemzése, a tágabb térszerkezet változásának feltárása és nem utolsó sorban a településdomborzati-vízrajzi viszonyok vizsgálata is sokat segíthet. Számos kisalföldi településen járva a belterület topográfiai jellemzői vizuálisan nem szembetűnők és a sürü beépítés miatt összefüggéseiben nem tekinthetök át. A településdomborzat és a vízrajz részletes történeti vizsgálata azonban a legtöbb esetben a felszíni viszonyok és az ösi településszerkezeti elemek közötti szoros kapcsolatra derít fényt (Somfai 2001c).

A következőkben a kisalföldi mezővárosok egy részét mutatjuk be 1784. évi, ill. jelenkori térképpárokon a legfontosabb történelmi tények, településalaprajzi értékjellemzők és a jövőbeni fejlődési lehetöségek felvázolásával. A jelenkori térképekre is rájelöltük a már 1784-ben is létező ösibb településrészeket, ahol a legtöbb, védelemre érdemes történeti jelentőségú alakzatokat találjuk. Cél, hogy a rendezési tervek készítése során ezeket lehetőleg tartsuk meg, vagy pedig - ha a változtatás indokolt - a történelemböl tanulva értö módon avatkozzunk be, ill. bővítsük településeink szerkezetét.

A soros (legtöbbször útifalu eredetủ) településalaprajzok vizsgálata nem nélkülözheti a települések közöttj útvonalak gondos elemzését, hiszen azok legtöbbje mára megváltozott, vagy esetleg el is tünt - sokszor jelentős torzulást eredményezve ezzel a település belső struktúrájában is (pl. Halászi). Megemlítünk néhány településfejlesztési feladatot is, ami nemritkán épp egy-egy szomszédos településsel való természetes útkapcsolat „felélesztése”, kiépítése kapcsán keletkezik (utcaszélesítés, új fejlesztési területek kijelölése, válaszadás a települési belső értékek átrendeződésére stb). A jövőben egyébként egyre több ilyen feladatra lehet országszerte számítani.

\section{Fertőrákos}

Az egyetlen Sopron közeli község, amely nem tartozott Sopron jobbágyközségei közé, a falu és a kőfejtő ugyanis a győri püspöké volt. 1582-ben emelkedett mezövárosi rangra, ezt követően fallal vették körüll. A török alatti elnéptelenedést követỏen Ausztriából és Morvaországból hoztak ide telepeseket. A 18. század elejére a település már túlnőtt a várfalakkal védett területeken. 
Somfai Attila : Kisalföldi és alföldi mezővárosok különbözősége, kisvárosi értékek védelme. Tér és Társadalom 16. évf. 2002/1. 59-98. p.

A legrégebbi településmag a püspöki vár és a malom területén lehetett. A község korábban egyutcás település volt, két orsósan kiszélesedő térséggel. A szalagtelkes települési jelleget csupán a püspöki kastély körüli - majorsági épületekből, cselédházakból, kocsiszínekből álló - kis szer jellegủ településrész bontotta meg. Később a föutcát mindkét végénél tovább építették, söt mellékutcákkal, kisebb-nagyobb teresedésekkel is bővült az egykori mezőváros.

A várost lényegében csak a fỏutca bejáratainál védelmezték városfal-szakaszok. A település két hosszabbik oldalát egymás mellé épített csürök, ill. kerítések védelmezték - ez a fajta védelmi rendszer az utólagos német települési behatásokról árulkodik (Mendöl 1963). E jellegzetesség Fertőrákoson már nagyobbrészt eltünt, de a megye más településein még ma is jól felismerhetö. Fertőrákost keleten a Fertő ingoványai, nyugaton pedig a Rákos patak is védték. A történeti településmag egy részét nemrég világörökségi listára terjesztették fel - építészeti és településszerkezeti értékei, történeti egységessége folytán.

A település jövője nagy lehetőségekkel kecsegtet. A ma még Sopronba ingázó munkaeröt is helyben kívánják foglalkoztatni. A kőfejtö-színpad és a Fertö-tavi vízisport-telep üzemeltetése mellett a jövőben gyógyvizek hasznosításával számolnak. Fertỏrákos idegenforgalmi vonzerejét fokozza a település hagyományos többnyelvűsége. Célszerü lenne kiépíteni a Sopronnal 3 km-rel rövidebb kapcsolatot adó nemeskúti utat.

\section{Szany}

Keresztutcás település. Már 1427-ben mezőváros volt. A győri püspökség keszöi várához tartozott. 1740 táján a püspökség saját kezelésbe vette a falut és az urasági majort.

A korábban feltehetően egyutcás szalagtelkes település a Rábával párhuzamos északkelet-délnyugati dủnesorra települt, ez örzi valószínüleg a Savaria-Arrabona út vonalát is. A későbbi keresztutca beépítése a 18. század végén egyre jelentősebbé váló Sopron-Kapuvár-Pápa-Bakony távolsági út mentén történt. A távolsági út helyét délen a marcaltői Rába-átkelés, északon a Sárdos-éri gázló jelölte ki.

A jövőben lehetőség van a mezőgazdasági feldolgozó központ-jelleg erösítésére. Sajátos miliőjủ a püspöki pihenőkastély és környezete. Élénk a forgalma a rábai strandnak is. Szanyon halad át Bécs-Hegyeshalom-Pápa-Bakony idegenforgalmi folyosó is. Az árpási út teljes hosszban történö kiépítésével Tét és Győr felé jelentösen javulnak a kapcsolatok.

\section{Csorna}

Csorna a Győrből Sopronba tartó forgalmi tengely és egy észak-déli európai föút kereszteződésében helyezkedik el. Piacáról már a 12.-13. századi oklevelek is megemlékeznek (Ollram 1941).

A legkorábbi településrészt, a „kettős szeres” településmagot a mai centrum keleti részében, az egyházi igazgatást képviselö prépostság környékén kell keresnünk. A keleti nagyobb Prépost-szer és a vele szemben fekvő nyugati Herceg-szer is egyegy magaslatra települt. Közöttük a központi fekvésủ, mai Szent István téren kisebb 
tó volt, melyet csak a 19. században töltöttek fel. A Prépost-szer mellett elhaladó Sopron-györi föút merev nyomvonala jóval később jött létre.

A település központjában máig lazábban beépített területsávot érzékelünk - ez az egykori belsőmajor zónája, melyen néhány évtizede még csak mezögazdasági épületek, cselédlakások, a kiskastély, ill. szemben a premontrei prépostság épületei álltak. A jó adottságú központi fekvésủ területek szabadon hagyásának kényszere folytán a 15-19. századi településfejlödés a déli és északi részekre szorult (Alsószer és Felső-szer). Ezek a településrészek szerkezetileg a településmagnál szabályosabbak, telepített jellegüek.

Az Alsó-szer a 17. században keletkezhetett, területét eredetileg három széles, dél felé tölcséresedő hosszú utca osztotta meg. A településrész mezövárosias karakterét a fésüs beépítésủ házak oromfalas homlokzatai és a közéjük épített nagykapus, tömör kerítések adták. A Felsö-szer ezzel szemben tipikus egyutcás településbővület, és szerkezetében nagyon hasonlít a török kiüzése után újjáépült mérnöki faluk felépítéséhez. Telkein az 1830 körüli térképek szerint szintén fésüs beépítésü házak voltak.

A jövőben Csorna mezőgazdasági gyüjtö-elosztó központi jellege bizonyára erősödik. Közlekedési csomóponti helyzete kiugró gazdasági és idegenforgalmi lehetőségeket ígér. Termálfürdője idegenforgalmi bázissá fejleszthető tovább.

\section{Hédervár}

Legrégibb településmagja az a favár, melyet 1142-ben Hedrych-Héder lovag építtetett. A Hunyadiak korában lett mezőváros, a 16. század elejétől már mint a lerombolt várhoz tartozó helyként írják le. A szeszélyesen kanyargó egykori MosoniDuna medrek által meghatározott hátakra telepedett, több „szer”-böl álló ún. szigetközi típusú nőtt falu. Még ma is kitapintható Hédervár telepưlésszociológiai értelemben vett kettős arculata. Az északkeleti részen települt egykor a gazdafalu, a kastély körül pedig az uradalom cselédsége.

A Szigetköz központjában fekvő festői településen idegenforgalomban, víziturizmusban, emellett a mezőgazdasági feldolgozóipar (húsipar) továbbfejlődésében rejlenek lehetőségek. Kíméletes településrendezési beavatkozásokkal minőségileg javítani indokolt a kastély és a falu építészeti-térbeli kapcsolatát. A mecséri út kiépítésével az idegenforgalmi kapcsolat az autópálya felöl jelentősen javulna.

\section{Mihályi}

Árpád-kori település. Kezdetben királyi várbirtok, a nyugati gyepủ vonalának Kapuvárhoz tartozó egyik megerösített helye. 1666-ban országos vásár tartására kapott engedélyt.

Folyóátkelőnél alakult ki az eredetileg egyutcás település, amely később a KisRábával párhuzamos keresztutcával bővült és mára összeért az északról szomszédos Kisfaluddal.

A 19. században a nagytérségi szerkezeti átalakulások nyomán a község fokozatosan elvesztette jelentőségét. Ma Kapuvár és Beled közelsége miatt nem várható kisközponti szerepének visszaszerzése. Amennyiben a beledi út kiépülne, a Bala- 
Somfai Attila : Kisalföldi és alföldi mezővárosok különbözősége, kisvárosi értékek védelme. Tér és Társadalom 16. évf. 2002/1. 59-98. p.

tonra irányuló kerékpáros idegenforgalom a Kisfalud-Mihályi-Vica-Beled belső, kisforgalmú útvonalon haladhatna.

\section{Mosonmagyaróvár}

A Mosoni-Duna déli partján húzódó Bécs-Pozsony-Buda országútra települtek Magyaróvár és Moson mezővárosok, amelyekböl 1939-ben jött létre Mosonmagyaróvár.

A Duna és a Hanság ingoványai közötti alacsony dombon alakult ki Moson. Szent István idejében megyeközpont lett, királyi földvár is épült itt. A 13. században Ottokár cseh király nagymérvủ pusztítása nyomán a megyeszékhely átkerült Magyaróvárra és ott új várat építettek. A maj Magyaróvár helyén római település, a Pannóniát északról védỏ limes egyik tábora volt: Ad Flexum. Magyaróvár a 14. században megkapta a királyi városok kiváltságait, „,szabad királyi mezöváros” lett (ez az elnevezés a „civitas” és „oppidum” fogalom korai, részbeni keveredését mutatja).

A kettős központú településszerkezetet hárompólusúvá tette az első világháborúban felépített fegyvergyár, amely a Monarchia legnagyobb ilyen gyára volt. Magyaróvártól északra kertvárosi település van, az ún. Majorok. A 20. század elsö felében a belvárostól keletre alakult ki a Károly-liget nevü kertes-villás település. Az 1939-ben egyesült két ősi település közötti terület pedig 1920 és 1980 között épült be. A városszerkezetben Trianon után irányváltást jelentett, hogy a Bécsbe menő forgalom átterelődött pozsonyiról a Bruck-i irányba. Ez a változás újabb teruiletek beépítését ösztönözte.

Ma a Duna menti és az adriai-balti európai utak kereszteződésében lévő város idegenforgalmi, ipari, kereskedelmi szempontból egyaránt vonzó település.

\section{Halászi}

Az Árpád-korban mosoni-dunai gázlónál alakult ki az eredendően egyutcás település. Elsỏ lakói a mosoni várbirtok szolgálatában álló halászok, később gyümölcsszállitók voltak. A 16. században kapott mezővárosi kiváltságokat. Az 1713. évi pestisjárvány után jelentös német és horvát betelepítés történt.

Az egyutcás szerkezet a 19. századi birtokátszabás (és úteltérítések) hatására eltorzult. A 20. században a település nyugati irányú bỏvítése szervetlenül történt.

Az utóbbi években a Mosonmagyaróvárról megindult kitelepülés, ill. Mosonmagyaróvár Halászi irányába történt bővítése a község agglomerációs típusú fejlődését vetíti elöre. Ha az ősi falutengely keleti felét püski irányába ismételten megnyitnák, visszaállna a településszerkezet egykori természetessége.

\section{Rajka}

Az Árpád-kori falu a Mosoni-Dunát kísérő magaspartra telepullt. 1721-ben lett mezőváros. Az eredetileg egyutcás falu a már kétszáz évvel ezelött megtörtént föútkihelyezés után több keresztutcával bövült a foút és a késöbbi vasútállomás felé. A település elmúlt két évszázadban történt további bővítései szervetlenül kapcsolódnak az eredeti településtengelyhez. 
A 18. században nagyszámú német és horvát betelepítés történt. 1945 után a kényszerủ lakosságcsere gyökeresen megváltoztatta a falu életét. 1947 óta, a három Pozsony környéki község elcsatolása óta határállomás múködik Rajkán.

A vállalkozásbarát környezetben a ma is jelentỏs ipari-szolgáltatási létesítmények számának további növekedése várható, távlatilag pedig a pozsonyi agglomerációhoz történő kapcsolódás. A hegyeshalmi útirány újjáélesztése az alakuló rajkai iparterület megközelítését segítené. A deustsch-jarndorfi (járfalui) földút kiépítése a már ma is időszakosan müködö határkapcsolatot emelné idegenforgalmi útvonallá.

\section{Kapuvár}

Kapuvár Sopron és Györ között kb. félúton helyezkedik el. Évszázadokon át Sopron vármegye egyik járásának székhelye, 1871-töl nagyközség. 1950-től GyörSopron megyei nagyközség, 1969-töl város (Varga 1998).

A település legelső lakói a vízjárta síkból kiemelkedő rábai és répcei hordalékkúpvonulatokon telepedtek meg. Már az illírek korában (i.e. 4. század) földvár volt e helyen. A honfoglalás után a gyepủrendszer őrhelye, kapuja volt. A vár és a szomszédságában 1663-ban alapított Garta a település ösi magjai. Kapuvár lakói a 16. század elején föleg hajdúk voltak. Kiváltságos helyzetükből fakadóan Kapuvár már 1558-tól oppidum, majd több évszázadon át hatalmas kiterjedésủ földesúri birtok uradalmi központja (Faragó 1974).

A település ősi tengelyei - a Sopron, ill. Babot felé vezető szalagtelkes utcák folyami hordalékkúp-vonulatokat követnek. Ettől eltéröen a városból ma kivezető Győri út vonalát tervezőasztalon húzták meg az 1930-as években. A 18. században megnyúlt a föbb utak mentén, ill. az északi jó termőterületek irányába, majd fokozatosan kiterebélyesedett. Az ún. földesúri belső major beékelődő területe azonban egészen a 20. századig megmaradt a településközpont közelében. A 19. században erőteljes besürüsödés volt tapasztalható az árvíz korlátozta településterületen.

1876-ban megnyitották a Győr és Sopron közötti vasútvonalat, amely Kapuvárt egyértelmủen a két város közötti kelet-nyugati tengelyre rögzítette. Vasúti csomópont is lehetett volna, ha a tervezett Celldömölk-pozsonyi és/vagy a Pápa-pozsonyi vonalak kapcsolati helyét nem engedi át Fertőszentmiklósnak, ill. Csornának (Gimes 1972). A kezdeti tervekkel ellentétben a város súlypontjától távol és délre telepített vasútállomás is a lehetségesnél kevesebb fejlesztőerőt fejtett ki (Lovas 2001).

1923-ban Kapuvár nagyközség és Garta község egyesült. Az 1930-as évek elején, majd az 1950-es években is nagymérvü lakótelek-osztás történt a város északi részén az uradalmi nagybirtok területén, így alakult ki a mai Házhely városrész. Az 1960-70-es évek intenzív iparfejlesztése a várossá válást segítette elő. Kapuvár 1969-ben a közeli községek bevonásával városkörnyékké szerveződött. A rendszerváltozást követően a környéki községek önállósodtak.

Napjainkban egyre élénkülnek Kapuvár országhatáron átnyúló gazdasági-üzleti kapcsolatai. A város 2000-ben megpályázta és elnyerte az ipari park rangot. A 
Somfai Attila : Kisalföldi és alföldi mezővárosok különbözősége, kisvárosi értékek védelme. Tér és Társadalom 16. évf. 2002/1. 59-98. p.

2000-2006 évekre részletes programtervet dolgoztak ki a Ipari Parkkal és a termálturizmussal kapcsolatos fejlesztések megvalósítására.

\section{Kisvárosok a mai és jövỏbeni településhálózatban}

Ma világunk értékrendjét egyre inkább a városiasodás, a városi életforma határozza meg. A nemzeti és nemzetközi mezőgazdasági kereskedelem és az agráripar szinte kiszorította a parasztságot az élelmiszertermelésben betöltött évszázados szerepéböl. 1945 óta nagymérvü foglalkozás-átstrukturálódás történt. 1945 után a Kisalföld egykori mezővárosaiban még közel 50\% volt a mezőgazdasági keresők aránya (Enyedi 1988). A következő évekre jellemző a keresők fokozatos átrétegződése az ipari és a szolgáltató szektorba. Az ötvenes és még inkább a hatvanas, hetvenes években a várossá kiemelt egykori mezővárosokban (Kapuvár, Mosonmagyaróvár, Csorna) intenzív iparfejlesztés történt, ezután a keresők majdnem fele már az iparban dolgozott. Ezekbe a településekbe a környéki falvakból ingázni is kezdtek - bár részben csak szezonális jelleggel (Rétvári 1974). A rendszerváltozással az ipar fokozatos minőségi átalakulása mellett föleg a szolgáltató-szabadidös szektor további erỏsödése várható.

A trianoni döntés nyomán a kisalföldi településhálózat - Pozsony elkülönítése ellenére - összességében kisebb térszerkezeti torzulást szenvedett, mint az Alföld, amely keleten jelentősen meggyengült Arad, Nagyvárad, Szatmárnémeti, ill. a partiumi vasútvonal határon túlra kerülésével. A kiesö szervező szerepet Szeged, Békéscsaba, Debrecen és Nyíregyháza csak lassan és hiányosan vette át. ÉszakDunántúlon ilyesmi nem történt, azonban igazi nagyváros hiányában több hasonló rangú város rivalizálása jellemzö.

Trianon után a legtöbb vasúti és közúti mellékvonalon megszüntették a határátjárást. A Kisalföldön a közlekedési hálózatok kényszerủ megváltozásával elsősorban a kisebb telepưlések - köztük néhány egykori mezőváros - a korábbinál elönytelenebb térszerkezeti helyzetbe kerültek. A határátkelök fokozatos újranyitása enyhíti a térszerkezeti hiányosságokat, újrafogalmazódnak a gazdasági és szomszédsági kapcsolatok. Észak-Dunántúl lakosságának egy kis része már a szomszédos Ausztriában vállal munkát.

A termelési módok gyökeres átalakulása, a térszerkezeti átrendeződés kihatott a városhálózat fejlódésére is. Egyes telepullések dinamikusan továbbfejlődtek, míg mások megtorpantak, ill. megrekedtek a fejlödésben. Az egykori kisalföldi mezővárosokat mai állapotuk szerint négy fö kategóriába sorolhatjuk (az időközbeni névváltozásokat nyíllal jelöltük):

1) Mezővárosból kis-, ill. középméretủ várossá lett, város-jelleg tekintetében folyamatosan továbbfejlődő települések (Pápa, Kapuvár, Csorna, Kisbér, Devecser, Ság-Kiscell $\rightarrow$ Celldömölk),

2) Mezővárosból nagyközséggé, községgé visszaminősített olyan települések, amelyek a jelenkori térszerkezetben is kedvező helyzetük és szerepük alapján 
Somfai Attila : Kisalföldi és alföldi mezővárosok különbözősége, kisvárosi értékek védelme.

Tér és Társadalom 16. évf. 2002/1. 59-98. p.

a jövőben kisebb ellátó központ (kisváros) jellegükben erösíthetök (Rajka, Hédervár, Lébény, Mosonszentjános $\rightarrow$ Jánossomorja, Beled, Szany, Tét),

3) Mezövárosból faluvá visszaminősített olyan települések, amelyek léptékük és a jelenkori térszerkezetben elfoglalt kedvezötlen helyzetük alapján a jövöben sem számíthatnak arra, hogy térségük kisebb ellátó központjává fejlődjenek (Mihályi, Szil, Tüskevár, Somlószölös),

4) Önálló mezővárosból más városok agglomerációjába betagozódó települések (Györ melletti Gönyủ vagy a Mosonmagyaróvár melletti Halászi).

Ha a volt mezövárosokat és az egykori mezövárosoknak megfeleltethető léptékủ mai kisközpontokat együttesen vizsgáljuk, akkor egy ötödik kategóriát is felállíthatunk:

5) Olyan települések, melyek nem voltak mezővárosok, de mára kisebb ellátó központtá fejlödtek. Ezek egy részét a városhiányos területeken (ilyen a Kisalföld belseje) célszerü várossá fejleszteni (pl. Bábolna).

Az 1971-es Országos Településfejlesztési Koncepció (VÁTI) az országban 210 települést irányzott elỏ központi funkcióra, figyelembe véve a városhiányos térségeket is. Ezen „öntudatra ébresztett telepuilések” egy része később kiharcolta a várossá nyilvánítását. A várossá nyilvánítások nem egyenletesen és nem következetesen történtek (1997-ben város lett például az 1500 lakosú Zalakaros üdülöfalu is). Egyes területek városhiányosak maradtak a mai napig. A településhálózat egyenetlenségei összefügghetnek földrajzi, történelmi vagy igazgatás-hierarchiai tényezőkkel, de ellensúlyozhatók a tudatos településhálózat-fejlesztési politikával (Lovász 2000). A településhálózat jövőbeni minőségi továbbfejlesztését illetően felmerül a kérdés, hogy helyes-e csupán a szélsőséges „város” és „falu” kategóriákban gondolkozni. Véleményünk szerint a városhiányos területek hiányzó központjaiként hasznos lehetne egy köztes, ún. „,kisváros” közigazgatási kategória is, amely természetesen a történelemböl ismert mezővárosok szerepével csak távolról rokonítható (a mezőváros kategória nemcsak történelmi okokból nem hozható vissza, hanem azért sem, mert a hagyományos értelemben vett mezőgazdálkodás településformáló ereje a múlté).

Györ-Moson-Sopron megye déli határa mentén kelet-nyugat irányban végighúzódó városhiányos területsávot találunk, ez azonban csupán részben magyarázható a Rába-szabályozások előtti mostoha kömyezeti adottságokkal (Ihrig 1973; Pájer 1990). A városhiány konzerválásában a megfelelő feltáró utak hiánya is jelentős szerepet játszik (Szörényiné Kukorelli 1994). Az említett területsáv úthálózatfejlesztéssel élénkíthető, azonban a térségben a közeljövőben várossá fejlődni képes telepüilést alig találunk (Máthé 1994). Úgy véljük, hogy ilyen esetben a térségfejlesztö központok szerepét a hiányzó városok helyett a már javasolt ún. „,kisvárosok” tölthetnék be (Szany, Beled, Répcelak, ill. a 4000-es lakosú Csepreg, amely városi rangra emelkedett néhány éve).

A 20. században a vasútnak óriási szerepe volt a városfejlődés előmozdításában. Az 1980-as évektöl kezdve azonban e téren ismét a közút tölt be domináns szerepet. A föút- és autópálya-hálózat korszerüsítése mellett a jövőben várhatóan elötérbe 
Somfai Attila : Kisalföldi és alföldi mezővárosok különbözősége, kisvárosi értékek védelme. Tér és Társadalom 16. évf. 2002/1. 59-98. p.

kerül a falvak, községek, nagyközségek (gyakran egykori mezövárosok) közötti ún. településközi utak kiépítése. A kisebb települések közötti közvetlen összeköttetések megteremtésével nagyban oldódhat az országos, megyei és járási szinten is sugaras alaprendszerü úthálózatunk, amely az egykori hatalmi-igazgatási rendszert képezte le. A körirányú kapcsolatok erősítésével, az úthálózat policentrikus rácsrendszerüvé fejlesztésével demokratikusabb térszerkezet alakul ki. A kisebb települések elött így újfajta gazdasági-kulturális távlatok nyílnak meg (Somfai 1998).

$\mathrm{Az}$ ismertetett településfejlödési folyamatok tanulságaként a magyar városhálózat egy lehetséges jövőképét - a múltból kiindulva és a jelenkori fejlődési tendenciákat, szükségleteket figyelembe véve - a következőképpen lehet felvázolni: a magyarországi városhálózat-terminológiát differenciálni indokolt föváros, megyei jogú város, (közép)város és kisváros kategóriákra (a besorolás kritériumai további kutatással pontosítandók). A kisvárosok - hozzávetölegesen 10000 lakosig - a térszerkezet kisebb falucsoportjaiban (kistérségekben) ellátó kisközpont szerepét töltenének be. Ilyenek lennének egyes volt mezővárosok és olyan települések is, amelyek ugyan nem voltak mezővárosok, de a mai városhiányos területeken a kisközpontok szerepét a jövőben elláthatják. A térszerkezet-fejlesztés egyik célja, hogy biztosítsa a kisközpontok megfelelö területi eloszlását, ezáltal tegye lehetővé a kistérségeken belül a nagyjából egyenletes ellátást és segítse elő megfelelö munkahelyek teremtödését. Egy-egy kistérség központja látná el a korábbi mezővárosokéhoz csak távolról hasonló feladatokat. A kistérségek napjainkban "tanulják" meg például, hogy fejlesztési programjaik megfogalmazása után miként pályázhatnak meg és használhatnak fel európai uniós és hazai vidékfejlesztési támogatásokat - a partnerség és a szubszidiaritás jegyében (Sain 2001).

Településhálózatunk távlati fejlődésének modellezésekor változtatás nélkül nem vehetô át a fejlett országok hálózati struktúrája - mások a történelmi és társadalmi feltételek. A településrendszer fejlödése igen bonyolult folyamat, igazából nem irányítható, nem tervezhető, csak befolyásolható. A tervezők feladata, hogy a településfejlödés spontán törvényszerüségeit időben felismerjék és helyes korrekciókkal a fejlödést tudatosan elősegítsék (Enyedi 1988).

A térségi településstruktúra átalakulása-átalakítása nem csak az ellátás körülményeire és a munkaeröpiacra van hatással: befolyásolja az önkormányzatok költségvetési politikáját, de akár egy település ingatlanforgalmát is. A központi jellegủ rendeltetések erősödése, ill. a hatására megmutatkozó fokozott kereslet hatással van a meglévő épületállomány sorsára. Megnő az igény a bontás, felújítás, bỏvítés, ill. új épületek építése irányába, emellett a települések peremterületein is megnő az építési telket keresők száma.

A szakembereknek helyes válaszokat kell adni a település életképességét mutató új funkciók (pl. kisüzem, benzinkút, telephelyek, bevásárlóközpont, diszkó stb.) városképi befogadására, müszaki-építészeti megfeleltethetőségére is. Ehhez a túl merev, alapvetően tiltó szemléletủ építésszabályozást fel kell váltani az alternatívákat is hordozó és azokhoz okos peremfeltételeket rögzítő épitésszabályozással. Például az új típusú lakótelkeknek a hagyományos lakófunkció mellett a számtalan és 
Somfai Attila : Kisalföldi és alföldi mezővárosok különbözősége, kisvárosi értékek védelme.

Tér és Társadalom 16. évf. 2002/1. 59-98. p.

TÉT XVI. évf. 2002

szerteágazó ủj igénynek is meg kell felelnie (a korábban ,garázsba kényszerült" vállalkozások helyett a lakóỏvezetbe még ,beférö", korszerủ csendes törpeuizemek stb).

A központi jellegböl fakadó intenzívebb fejlödés nem csupán a műemlékek, hanem az általános városképi értékek, sôt a természeti értékek védelmében is fokozott figyelmet kíván.

\section{Mezővárosi értékek védelmének lehetöségei}

\section{Mit és hogyan lehet reálisan megörizni?}

A társadalmi-gazdasági változások, erkölcsi avulás a környezetünket alkotó elemek átépítésével, pusztulásával, lebontásával járhat, ez az élet természetes velejárója. Fontos ezért megnevezni a meglévő épített és táji-természeti környezet azon részét, melyet meg kívánunk örizni. Erre azért is szükség van, hogy a közösség érdekében megóvandó objektumok ne essenek egyéni érdekek áldozatává. A megörzés akkor hatékony, ha a helyi közösség felé kellöen meg tudjuk indokolni annak szükségességét: a védelem nemcsak történeti szempontból fontos, hanem azért is, mert a meglévö települési környezet az identitástudatot erösíti, a településre jellemző egyéni és társadalmi létformákat öriz, az emberbe mélyen bevésődő ,itthon vagyok" tudat természetes közegét jelenti. - A települési értékek bemutatására alapozott idegenforgalomnak köszỏnhetően számos formában jelentkező jövedelmek aláhúzzák a történeti településrészek megörzését a gazdaságosság oldaláról is.

A múlt legnyilvánvalóbb emlékeinek - várak, kastélyok, mủemlékek, terek, történeti parkok - megbecsülésén túlmenöen cél a történeti, kulturális és természeti értékeket hordozó mezővárosi épített és táji környezet komplex megóvása. Védeni indokolt egyes építményeket (müemlékeket, helyi építészeti emlékeket, népi mủemlékeket) és kapcsolódó környezetüket. Védendők a település morfológiai értékei: településszerkezeti adottságok, térarányok, beépítési módok. Jellegzetes utca- és térrészletek: városképi, ill, telepủléstörténeti szempontból értékes rétegezett együttesek, épületcsoportok. A települési értékek védelme a befogadó táji-természeti környezet védelme nélkül nem lehet teljes.

A lakosságban tudatosítani kell saját településük értékeit és azt, hogy az értékek gazdái elsősorban ők maguk. Az állami szintü támogatási rendszerek mellett elsősorban települési szintủ programokat kell teremteni, hogy a helyi szereplök is aktívan rész vehessenek a megóvás, felújítás, továbbfejlesztés, felvirágoztatás feladataiban. A települési értékvédelemben tehát ugyanúgy a partnerség és a szubszidiaritás elvét kell követni, mint a kistérségi gazdaságstruktúra-fejlesztés pályázati rendszereinél. Az épített és környezeti elemek megörzésének fontos feltétele, hogy azok a település életének, vérkeringésének továbbra is szerves részei legyenek: funkciỏikat megörizzuik, ha arra ma is igény mutatkozik, vagy a revitalizálás során minél kevesebb változtatást igénylö új szerepeket kell találnunk.

Az Európa Tanács Kulturális Ơrökség Bizottsága 1993-ban kinyilvánította az, ,integrált értékvédelem" szükségességét. Ez a történelmi környezet fejlesztésénél azt 
Somfai Attila : Kisalföldi és alföldi mezővárosok különbözősége, kisvárosi értékek védelme. Tér és Társadalom 16. évf. 2002/1. 59-98. p.

jelenti, hogy demokratikusan elfogadott aktív tervezési-hatósági politikával legtöbbször meg lehet nyerni a befektetők bizalmát az iránt, hogy hosszú távon megfelelő pénzügyi nyereséget tudnak elérni. Ezáltal élénkíthető a helyi gazdaság, növelhetö a foglalkoztatottság is (Fejérdy 1996).

Az îrás következő, befejező részében összefoglaljuk a mezővárosi értékek védelmének lehetőségeit a regionális együttmüködésektől egészen a helyi védelemig.

\section{Regionális és interregionális együttmüködésekben rejlö lehetőségek, országos szintü értékfelmérés}

A történeti település jelentős gazdasági, társadalmi és kulturális érték. Ahhoz, hogy sorsa pozitívan alakuljon, a megtestesült örökség helyes ismeretére, helyes értékelésére van szükség. Az egyes régiók a történeti, kulturális értékeket örzö települések lényeges jellemzőit tudományos alapokon, közösen kidolgozott módszerek és irányelvek alkalmazásával kívánják vizsgálni és értékelni. Ilyenfajta együittmüködések színterei a Történelmi Emlékek és Helyek Nemzetközi Tanácsa (ICOMOS) keretén belül a Történeti városok és Falvak Nemzetközi Bizottsága (CIVVIH), ill. a nyugat-magyarországi térség számára az Alpok-Adria Munkaközösség.

Az Alpok-Adria Munkaközösséget 1987-ben olyan régiók hozták létre, amelyek történeti és kulturális örökségük alapján összetartozónak tekintik magukat: olasz, osztrák régiók, Horvátország, Szlovénia és nyugat-magyarországi megyék (GyőrMoson-Sopron, Somogy, Vas, Zala). A Munkaközösség Kulturális Bizottsága hozta létre többek között a Történeti Központok Albizottságát. Meghatározásuk szerint a történelmi központ olyan sürü, régi településszövetủ település vagy településrész, amely őriz egykori gazdasági, politikai, kulturális, vallási és társadalmi struktúrákat. A történeti településrészek az egész településsel (és a természeti környezettel) szoros kapcsolatban állnak, elszigetelten nem kezelhetök. Fejlesztésüknél egyetértésre kell törekedni a lakossággal, ehhez az iskolától a tömegtájékoztatásig minden eszközt igénybe kell venni. Az Albizottság 1987. évi második jelentésében a vidék történeti településeinek vizsgálatára szólított fel, ehhez kapcsolódtak a tagországokban folyó egyes kutatások is, pl. Fertörákoson (Winkler-Hartmann-Petzet 1992).

Pár évvel később már az is megfogalmazódott, hogy hazánkban az épített és természeti környezet értékeit országosan és szisztematikusan szükséges feltárni. Ezzel egyidejűleg a védendőnek ítélt karakterjegyeket olyan térinformatikai alapú adatbázisba kell foglalni, amely a térségi összefüggések (például a különböző fajta települési értékek sürüsödési helyeinek) kimutatására is alkalmas. Magyarországon ilyen adatbázis az Országos Területi Információs Rendszer (TEIR), amelybe 1998-ig a kultúrtájak és történeti kertek, a müemlékek, valamint a régészeti emlékeklelöhelyek kerülttek bele, de már elörehaladott a településszerkezeti és népi épitészeti-néprajzi adatok országos térinformatikai feldolgozása is (Máté 1999b). 
Somfai Attila : Kisalföldi és alföldi mezővárosok különbözősége, kisvárosi értékek védelme.

Tér és Társadalom 16. évf. 2002/1. 59-98. p.

92 Somfay Attila

TÉT XVI. évf. 2002

Táji arculat védelme, környezetvédelem, zöldterületek

Az egykori mezövárost és dülökre tagozódó határát egy egységnek kell tekintenünk. A vidéki táj szerkezetének változásai e határt érintik a legérzékenyebben. Arculata a történelem folyamán többször igen nagy mértékben átalakult, és ma is változik. A telkek átosztásakor, a tagosításkor vagy a melioráció (átfogó tájrendezés és talajjavítás) kapcsán gyakran fasorok, erdőrészek, dủlőket határoló cserjések semmisültek meg.

A természetvédelmet nem csak a természetvédelmi területekre, nemzeti parkokra kellene összpontosítani: a táji arculat részét képezik a kisebb erdőfoltok, vízfolyások, természetes vagy mesterséges tavak és a tájban ülö épített emlékek (kápolnák, kálváriák, egykori útelágazást őrző keresztek, gémeskutak stb.). Ezek egy részéről országos összeírás készült a kilencvenes évek elején az Útgazdálkodási és Koordinációs Igazgatóság kezdeményezése nyomán (Winkler 1997b). A hagyományos turista-útvonalak mellett tematikus tanösvények is létesíthetök. Kerékpárutak nemcsak közlekedési utakkal párhuzamosan vezethetők, hanem nyugati szomszédainkhoz hasonlóan természeti környezetben is (pl. felszámolt kisvasutak töltésein).

A településbelsö kultúrzöld-felületei és a külterületek táji környezete közötti átmenetet képviselő településszéli zöldterületeket indokolt lenne parkerdőkké, pihenökertekké fejleszteni. A településtől sétatávolságra $(1-1,5 \mathrm{~km})$ található kiemelt turista-úticélok (pl. az egykori mezővárosok szőlöhegyei, ,pincevárosai”, kálváriadombok, emlékhelyek) megközelítését telepített fasorokkal, sétányokkal indokolt gazdagítani. A településbelsőben a sokféle alakban megjelenó zöldjeinek ,gondozása" mellett a településtervezőknek nem szabad elfeledkezniük az újabb városi zöldterületek létesítésérỏl sem, és a településeken található, még rendezetlen zöldterületekben rejlö potenciális lehetőségeket is fel kell ismerniük (pl. folyópartok).

\section{Településszerkezet értékeinek védelme}

A települési örökség az épített kömyezet történeti települési értékeinek összessége. Nem egyszerủen a történeti objektumokat jelenti (épített örökség), hanem az azok által létrehozott térbeli rendet, az általuk megnyilvánuló településképet. A települési örökségnek igen fontos része a térbeli elemek sokasága között kirajzolódó településszerkezet, azaz az utca- és térrendszer, sỏt az épületek ,alatt” nyugvó telekrendszer is. A településszerkezet csak a településeket befogadó tájjal együtt értelmezhető igazán, tekintettel a történelmi léptékú gazdálkodási-életmódbeli és térszerkezeti kölcsönhatásokra (Máté 2001).

A települések - köztük a mezövárosok - településszerkezetének kutatásával többek közo̊tt Meggyesi Tamás foglalkozott. Tézisei összefoglalójában megfogalmazta, hogy az emberi környezet korlátlan számú egyetemes archetípusból épü] fel. A hagyományos környezetkultúrák gyakran korszerübb, használhatóbb megoldásokat hordoznak, mint a modernnek tekintett település- és lakásépítési szokások. Ennek a felismerésnek a kamatoztatásához azonban feltétlen túl kell lépni a müemlékvéde- 
Somfai Attila : Kisalföldi és alföldi mezővárosok különbözősége, kisvárosi értékek védelme. Tér és Társadalom 16. évf. 2002/1. 59-98. p.

lem hagyományos szemléletén, és értéknek kell tekintenünk azokat a településszerkezeti, elrendezésbeli, morfológiai és szellemi adottságokat is, melyek ma még sok helyen pusztulásra vannak ítélve. Új szemléletü kutatásokat kell végezni, melyeket a történeti földrajztudományra alapozunk (történeti térképek, helytörténeti monográfiák elemzésével). A települések vizsgálatakor ún. természetes övezeteket célszerü azonosítani (amelyekben az úthálózati rendszer, az épületeknek a telekhatárokhoz való viszonya, az épületek jellege és az ottélök társadalmi összetétele is többékevésbé homogén). A természetes övezeteket összehasonlító morfológiai elemzésnek kell alávetni, hiszen hasonló morfológiai típusok eltérő fejlődés eredményeképpen is létrejöhetnek (és fordítva: eltérő fejlődési utak során hasonló morfológiai típusok is keletkezhetnek). Az ún. genetikus tipológia keretében a morfológiai képletek történeti fejlödés során bekövetkező elváltozásait is fel kell tárni (elsősorban a beépítés és az épületkonfigurációk fejlődési fázisainak megállapításával). Meggyesi Tamás már 1994-ben megfogalmazta, hogy a fellelt értékeket telepuilési arculattárban célszerủ összefoglalni. Ehhez a tevékenységhez nem elegendő a településszerkezet és épületállomány ismerete. Empátia kell a térszituációról térszituációra feltáruló település, és a benne lakozó „genius loci” megérzéséhez, otthon kell lenni a részletek világában is (Meggyesi 1994).

A településszerkezet sokoldalú történeti elemzése olyan szemléleti átalakuláshoz vezethet, amely a meglévó értékek felismerésén és védelmén túlmenóen a beavatkozások-átalakítások, sőt az új településrészek tervezésekor is különleges értéktöbblet-teremtó igényként és érzékenységként jelenik meg - szemben a sematikus gondolkodásmóddal. A településtervezők asztalán a meglévö településszerkezet formakincséböl intuitíve táplálkozva olyan új településrészek születhetnek, amelyeknek kellően hierarchizált és a történetihez hasonló változatosságú út- és térrendszerük van. Mindehhez természetesen a mai kor igényeinek is megfelelő telekalakítást és beépítésmódokat indokolt párosítani (Somfai 2001b).

\section{Müemlékvédelem}

Az 1997. évi LIV. megújított múemlékvédelmi törvény áttörést hozott a kisvárosok mủemlékvédelmében is. Ez a törvény már nem hatályos, mivel helyette a még komplexebb szemléletü kulturális örökségvédelmi törvény lépett hatályba (2001. évi LXIV. törvény).

1997-ben megszüntek a régi „mủemlék”, „mủemlék jellegü épület”, „városképi jelentőségủ épület" kategóriák. Ezek helyett a korábban összefoglaló névként is használt „Müemlék" fogalmat vezette be a törvény, ezzel kiküszöbölte a vétlen vagy akaratlagos félreértelmezéseket, amelyek már igen sok kárt okoztak (,csak” múemlék jellegű). Új fogalmak is születtek: „múemlék”, „múemléki jelentőségü terület”, „műemléki környezet”, és „múemléki helyreállítás”, „védett mủemléki terület” (a ,müemléki jelentőségü területek” és a „múemléki környezet” tartoznak bele). Az 1997. évi törvény kiemelte, hogy a mủemlékeket nem szabad zárványként kezelni. Meg kell akadályozni az olyan „megoldásokat”, melyek azelött kézenfekvő 
Somfai Attila : Kisalföldi és alföldi mezővárosok különbözősége, kisvárosi értékek védelme.

Tér és Társadalom 16. évf. 2002/1. 59-98. p.

beépítendö területnek tekintették a kastély parkját, a templom kertjét, és így évszázadokkal ezelött kialakult történeti városmagokat, városszerkezetet robbantottak széjjel - a mai teleknagyságok és beépítési százalékok alkalmazásával. Az 1997. évi törvény már nem egyedi müemlékek védelmében, hanem összefüggésekben kívánt gondolkodni. A mủemlékek szorosan vett környezetét (a szomszéd ingatlanokat) és a mủemlék tágabb környezetét is bizonyos kontroll alatt szándékozott tartani. A 2001. évi kulturális örökségvédelmi törvény szerint a kulturális örökség felöleli a régészeti érdekü területeket, a régészeti lelöhelyeket védőövezeteikkel, a régészeti emlékeket, a mủemlékeket, a mủemléki értékeket és mủemléki területeket, valamint a kulturális javakat. A müemléki érték fogalmába épített örökségi elemek tartoznak (történeti, mủvészet, tudományos vagy müszaki emlékek), valamint ezen elemek rendeltetésszerủen összetartozó területe, együttese, rendszere. Figyelemre méltó, hogy mủemléki védelem alá vonhatók a történeti kertek, temetők, ső̉ olyan történeti táj(egységek) is, amelyek a természet és az ember együttes munkájának ered ményei és kulturális szempontból jelentősek.

Egykori mezővárosok történeti belvárosainak új szemléletủ rehabilitációi közül szép példa Kapuvár fötéri tömbje, ahol a patinás épületek felújításán túlmenöen azokat új módon kapcsolták be az élet vérkeringésébe az épületek részbeni funkcióváltásával, ill. azzal, hogy a hangulatos belső udvarokat a nagyközönség számára megnyitották. További módszertani újdonság a meglévő értékekre igen érzékeny, ún. telkenkénti építésszabályozás elve (Winkler 1980). A hiányzó foghíjak beépítésekor az új elemek tiszteletben tartották a meglévő térbeli rendszert - annak arányait és léptékét, minőségét. Nem bontották meg az együttes harmóniáját, hanem hozzájárulnak annak gazdagitásához. Hasonló gondolkodásmódra szólít fel a Történeti Városok Nemzetközi Chartája is, a melyet 1987-ben fogadtak el (Fejérdy 1996).

Történeti kisvárosainkban elsősorban a településmag és a történeti településrészek egyes részei szorulnak müemléki védelemre. Bizton védelemre számíthatnak a történeti településben „idegenforgalmi logo"-nak számító elemek: a vár, templomok, mủemlékek, történeti terek. Ezen felül az „Épített környezet alakításáról és védelméről" szóló (szintén 1997. évi) megújított építési törvény szellemében a helyi közösség is oltalma alá vonhat épületeket az ún. ,helyi építészeti emlékek” megnevezésével. A Nyugat-Dunántúlon Pápa egykori mezöváros volt az első olyan város, ahol 1997-ben a részletes rendezési terv kapcsán a „helyi müemlékek” listája elkészült (Winkler 1997a). Ma már ott tartunk, hogy a helyi jelentőségü emlékeket is figyelembe kell venni a településtervezés minden fázisában - erre 1990 óta a Granadai egyezmény is kötelezi hazánkat (Máté 1999b).

A helyi védelem céljait szolgálta korábban a ma is létező „Mủemléki jelentőségü terület" kategória. Föként városaink középkori belvárosait sorolták ide, ellenben az egykori mezővárosok védelmében csak kivételesen alkalmazták (pl. Hollókőn). Ezt az ürt a jövőben - föként rendezési tervek, ill. a helyi építésügyi szabályzat közvetítésével - a mủemlékvédelemnél tágabb értelmủ, komplexebb szemléletủ jellegvédelem (építész szóhasználattal karaktervédelem) töltheti be. 
Somfai Attila : Kisalföldi és alföldi mezővárosok különbözősége, kisvárosi értékek védelme. Tér és Társadalom 16. évf. 2002/1. 59-98. p.

\section{Jellegvédelem}

Történeti településeink - köztuik mezővárosias településeink - szépségét az épített közegnek a természeti látványhoz kötődése adja meg. A jellegvédelem az épített elemek és az azokat befogadó táji környezet együttesének védelmét jelenti (nem keverendő a tisztán természeti környezetre figyelő természetvédelemmel). A jellegvédelem (más szóval karaktervédelem) fontosságát Pogány Frigyes évtizedekkel ezelött az elsők között ismerte fel és hangoztatta.

A jellegvédelem az értékesnek felismert tájba ágyazódó építészeti együttes lehető látványi fenntartása a megváltozott gazdasági, társadalmi, müszaki és egyéb adottságok mellett. Túlmutat a müemlékvédelmen annyiban, hogy az építészeti együtteseket nem történeti hüségükben kívánja fenntartani, hanem elsősorban a környezetükhöz való viszonyukban. Amennyivel ez a kritérium pontatlanabb, annál nagyobb körültekintés és dinamizmus szükséges teljesítéséhez (Kubinszky 1995).

A jelleg az épített közeg és természeti környezete közötti egyensúly sajátos esete. Ilyen például az alföldi mezővárosok belső képében az akácfák + földszintes házsor, vagy a mezỏvárosokhoz kapcsolódó szölöhegy + a vincellérházak. Sok esetben harmadik tényezỏ is belép: terep, tópart stb. Évszakok szerint is változhat a fô tényezők dominanciája.

A jelleg a kiterjedését illetően szükebb vagy néhány esetben nagyobb területre általánosítható. Szúkebb értelmü jelleg pl. Mezőkövesd földszintes házainak kertes negyede, tágabb a Keszthelytöl Füzfőig húzódó Balaton parti beépítés.

A jelleg sajátossága a változás is. Nemcsak a természeti környezet változik, hanem az urbanizálódás révén az épített közeg is. Gyönyörü fésủs beépítésü hagyományos telepuilésrészeink az agrártermeléshez szervesen kötődtek. A 20. század ötvenes éveitől a hetvenes évekig jellemző földszintes, sátortetős új építésü házakat idegennek éreztük a régi egyszerü zsúpfedésü, nyeregtetős házakhoz képest, pedig alapvetően a fejlödés, korszerüsödés megkövetelte módosulás volt (Székely 2001). A hagyományos telepuilés léptékével, a fásítással jobban összeegyeztethető volt, mint a kertes településrészeken késóbb épített, kétszer olyan magas, mai szemmel is kulturálatlanabb megjelenésü, léptékevesztett emeletes házak. A szakemberek felismerték a településképre leselkedö veszélyt, de a jellegvédelem eszköztárának hiányában nem tudtak mit kezdeni a korszerüsítés feszítő igényéből születő új építményekkel.

A történeti városmagok közlekedési tehermentesítését az elkerülő utak építése örvendetesen elősegítheti, azonban ez a nagy forgalmú és óriási területigényủ bevásárlóközpontok, áruházak városszélre településével jár. Kellő körültekintés hiányában ilyenkor könnyen felborulhat a táj és a település hagyományos kapcsolata. Ez a kivételes természeti környezetü településeket fokozottan veszélyezteti (Fejérdy 1996).

Tanulság, hogy a jellegvédelem eredményesen ott alkalmazható, ahol a szép látvány mögött az élet megkövetelte tartalmi optimum is fenntartható. A jellegvédelem komplex feladat, minden eset egyéni elbírálást kíván. A jellegvédelem (építész szóhasználattal karakterszabályozás) során jól megválasztott jelleg-tényezők közül 
Somfai Attila : Kisalföldi és alföldi mezővárosok különbözősége, kisvárosi értékek védelme.

Tér és Társadalom 16. évf. 2002/1. 59-98. p.

(pl. az épülettömegek léptéke, szintszám, tetöhajlásszög, tetőfedés anyaga, növényfajok stb.) csupán a legfontosabbak megtartását célszerủ előírni. Túl sok jellegzetesség elöírása nehezíti a betartást, a lényeges vonások mellőzése pedig hatástalanná teszi a védelmet (Kubinszky 1995).

\section{Záró gondolatok}

A vázolt történeti elemzések tanulságai az egykori mezöváros-hálózattal nem azonos mai kisváros-hálózat tudatos fejlesztését segíthetik. A nemzeti energia legcélszerübb felhasználása érdekében többek között figyelembe kell venni a települések gazdasági potenciálját, emellett tágabb térszerkezetük adottságait és jövőbeni lehetöségeit. A gazdasági szempontokon túlmenően a települések történeti településszerkezetét, az épített és természeti környezet harmonikus együtteseit indokolt megóvni, sőt jellegük lényegi vonásaira figyelemmel kell lenni az új építéseknél is. Ez nagyban hozzájárulhat ahhoz, hogy a „genius loci”, azaz a hely szelleme is megörzödjön, gazdagodjon.

A múltból a jövőbe mutató értéktudatos településfejlesztéssel lehet Magyarország igazán újra szerves része a sokszínü, egyéni arculatokból felépülö Európának.

\section{Irodalom}

Bácskai V. (1965) Magyar mezóvárosok a 15. szazadban. Akadémiai Kiadó, Budapest.

Bárth J. (1996) Szállások, falvak, városok. Kalocsai Múzeum, Kalocsa.

Beluszky P. (1999) Magyarország telepiilésfóldrajza. Dialóg Campus Kiadó, Budapest-Pécs.

Boros F. (1957) Adatok Magyarország telepúlésállományának XVII. századi fejlődéséhez. - Földrajzi Értesitö. 6. 459-474. 0.

Enyedi Gy. (1988) A városnövekedés szakaszai. Akadémiai Kiadó, Budapest.

Erdósi F. (1991) Kommunikáció és térszerkezet. Akadémiai Kiadó, Budapest.

Faragó S. (szerk.) (1974) Kapuvárról írásban és képekben. Városi Tanács, Kapuvár.

Fejérdy T. (1996) A történeti városok, a fenntartható fejlődés és a turizmus kapcsolatáról. - Müemlékvédelem. 4. 240-245. o.

Felhỏ I. (szerk.) (1970) Az úrbéres birtokviszonyok Magyarországon Mária Terézia korában. I. kötet: Dunántúl. Akadémiai kiadó, Budapest.

Fényes E. (1841): Magyar országnak s a hozzá tartozó kapcsolt tartományoknak mostani állapotja statisztikai és geographiai tekintetben, I. leíró kötet. Trattner-Károlyi Kiadó, Budapest.

Gimes E. (1972) Kapuvár Útikalauz. Győr-Sopron Megyei idegenforgalmi Hivatal, Györ.

Göcsei I. (1943) Kapuvári-Rábaköz földrajza. Horthy Miklós Tudományegyetem, Szeged.

Györffy I. (1943) Magyar falu magyar ház. Turul Kiadó, Budapest (reprint: Akadémiai Kiadó, Bp. 1987).

Győri R. (1999) Térszerkezeti változások a polgárosodó Kisalföldön. - Tér és Társadalom, 4. 77-106. o.

Hofer T. (1960) A magyar kertes település elterjedésének és típusainak kérdéséhez. - Müveltség ês Hagyomány I. 331-350, o.

Hofer T. (1980) A hazai tanyarendszer és a másodlagos telepúlésszóródás kủlfơldi példái. - Pőlőskei F.Szabad Gy. (szerk.) A magyar tanyarendszer múltja. Akadémiai Kiadó, Budapest, 9-60. o.

Ihrig D, (szerk.) (1973) A magyar vizszabalyozás története. Országos Vízügyi Hivatal, Budapest.

Istvánfi Gy. (1997) Az építészet története: Óskor, Népi építészet. Nemzeti Tankönyvkiadó, Budapest.

Iván L. (1994) Településföldrajzi sajátosságok a dél-alföldi Duna-vőlgy kơzépfalvaiban. - Földrajzi Értesitô. 1-2. 101-115. o.

Kubinszky M. (1995) Táj+építészet. Mezőgazda kiadó, Budapest.

Láng T. (1986) Településtervezés I. Kézirat. Tankönyvkiadó, Budapest.

László Gy. (1944) A honfoglaló magyar nép élete. Magyar Élet Kiadó, Budapest.

Lengyel A. (1944) Pusztult falvak, eltünt helynevek Győr megyében. Győr vármegye közönsége, Győr.

Lovas Gy. (2001) 125 éves a Györ-Sopron közötti vasútvonal. - Soproni Szemle. 3. 297-318. o. 
Somfai Attila : Kisalföldi és alföldi mezővárosok különbözősége, kisvárosi értékek védelme. Tér és Társadalom 16. évf. 2002/1. 59-98. p.

Lovász Gy. (2000) Magyarország telepuléshálózati térképei. - Teriiletfejlesztés - Regionális kutatások. Pécs. 191-199. 0.

Marosi S.-Szilárd J. (1974) Domborzati hatások a gazdálkodásra és a településekre. - Földrajzi Közlemények. 3. 185-196. o.

Martin, D. (szerk.) (1994) Második közös jelentés a történeti központokról. Mladinska Knjiga, Ljubljana.

Máté Zs. (1989) Szeged XVI. századi helyrajza. Tanulmányok Csongrád megye történetébôl. XIV. kötet. Csongrád Megyei Levéltár, Szeged. 5-57. o.

Máté Zs. (1998) Falusi telepúlések és településszerkezetek a Kárpát-medencében. - Falu Város Régió. 8. 14-21. o.

Máté Zs. (1999a) Korai falusi településszerkezetek a Kárpát-medencében. $\left(8^{\text {th }}\right.$ International Conference of Built Heritage Consevation, Tusnad, 1999) - Tusnad'99. 64-69. o.

Máté Zs. (1999b) A kulturális örökség mint térségi összeföggésrendszer. - Falu Város Régió, 6., 3-8. o.

Máté Zs. (2001) A városszerkezet mint müemlék. - Falu Város Régió. 6. 6-9. o.

Máthé M. (1994) Kistérségi funkciók ellátása, potenciális városok Györ-Moson-Sopron megyében. Falu Város Régió. 5. 39-41, o.

Meggyesi T. (1994) Az alföldi halmazos települések morfológiája. (Akadémiai doktori értekezés). Budapest.

Mendöl T. (1932) Táj és ember. Magyar Szemle Társaság, Budapest.

Mendöl T. (1963) Általânos településföldrajz. Akadémiai Kiadó, Budapest.

Mikó S. (1968) Jobbágysors Sopron megyében a XVIr. és XVIII. században. - Soproni Szemle. 1. 11-19. o. és 2. 123-129. o.

Novák L. (1986) Telepuilésnéprajz. Arany János Múzeum, Nagykőrös.

Novák L. (1989) A három város épitészete. Arany János Múzeum, Nagykőrös

Ollram F. (1941) Csorna telepielés- és gazdaságföldrajza. Egyházmegyei Nyomda, Györ

Papp-Váry Á. (szerk.) (1991) Történelmi világatlasz. Kartográfiai Kiado, Budapest.

Pájer I. (1990) Rábaköz népének védekezése az áradások ellen 1870-1889. Rábaközi Mủvelödési Egylet, Csorna

Perényi I. (1972) Telepulléstervezés. Tankönyvkiadó, Budapest.

Rechnitzer J. (szerk.) (1988) A Rábaköz térszerkezete. MTA RKK ÉDO, Csorna-Kapuvár.

Rétvári L. (1974) A foglalkozási - terùleti átrétegződés nêhány kérdése Györ vonzáskörzetében. - Győri Tanulmanyok. 2. 37-55. o.

Rosivall Á. (szerk.) (2000) Pannonhalma-Váralja szabályozási terv, vizsgálatok. Rosivall Tervező Iroda, Budapest.

Sain M. (2001) Társadalmi párbeszéd és partnerség a vidékfejlesztésben a kistérségi agrárstruktúra és a vidékfejlesztési programok kapcsán. - Falu Város Régió. 5. 18-19. o.

Simkovits Gy. (1965) A mezỏgazdasági termelés és a termelöerök fejlỏdésének néhány vonása Sopron megyében a XIX. század végén. - Soproni Szemle. 2. 115-126. o.

Somfai A. (1998) A helyi- és mellékutak hálózatảnak továbbfejlesztési lehetőségei. - Közúti és Mélyépítési Szemle. 12/ b. 515-522. o.

Somfai A. (2001a) A domborzat és a folyómeder-vándorlás szerepe Györ római kori és középkori telepưlésszerkezetének alakulásában. - Falu Város Régió. 1. 22-28. o.

Somfai A. (2001b) A domborzat szerepe a dunántúli települések szerkezetében. (10 ${ }^{\text {th }}$ International Conference of Built Heritage Consevation, Tusnad, 2001) - Müvelödés. 4. 21-24. o.

Somfai, A. (2001c) Geomorphology Based Settlement Structure Research on Nearly Flat Grounded Hungarian Cities (The $3^{\text {rd }}$ International Congress of PhD Students, Miskolc, 2001. augusztus 13-19.) Engineering Sciences. Volume II. 771-778. o. Miskolci Egyetem, Miskolc.

Soproni E. (1940) A kultúrsarok gondjai. A Magyar Társaság kiadása, Budapest.

Székely J. (2001) Sátortetôs családi házak. - Arc. 6. 30-43 o.

Szörényiné Kukorelli I. (1994) Répcesík, a centrum nélküli kistérség. - Falu Város Régió. 5. 42-45. o.

Tóth Z. (2000) Településkörnyezet II. Az épített környezet. - Enyedi Gy. (szerk.) Magyarország településkörnyezete. Akadémiai Kiado, Budapest. 151-185. o.

Tuba L. (szerk.) (1998) Györ-Moson-Sopron megye kézikönyve. CEBA Kiadó, Györ.

Varga J. (1998) Kapuvár. - Tuba L. (szerk.) Györ-Moson-Sopron megye kézikönyve. CEBA Kiadó, Györ. 489-509. o.

Winkler G. (1997a) Épített környezetủnk védelme a Nyugat-Dunántúlon, - Honismeret. 3. 27-32. o.

Winkler G. (1997b) Történeti utakon. - Közúti közlekedés-és Mélyépitéstudományi Szemle. 12. 447-448. o.

Winkler G. (1980) Kapuvár belváros részletes rendezési terve. Györ-Sopron Megyei Tanácsi Tervezö Vállalat, Györ.

Winkler, G.-Hartmann, U.-Petzet, M. (1992) Fertórákos. Karl M. Lipp Verlag, München.

Winkler G. (1998) A premontreiek és Csorna fejlödése. - Szalontai J. (szerk.) Tárgy és Jelentése. (Rábaközi tanulmányok). Csonai Múzeum, Csorna. 209-225. o. 


\section{THE DIFFERENCE BETWEEN THE MARKET-TOWNS IN THE GREAT HUNGARIAN PLAIN AND THE SMALL HUNGARIAN PLAIN, PROTECTION OF SMALL TOWN VALUES}

\section{ATTILA SOMFAI}

The author deals with investigations of historical Hungarian settlements, widely in time and space, mainly villages and oppidums (market-towns) on the North-Transdanubian part of Hungary. His investigations are focused on the structure, i.e. on street and square composition, and also on parcel system.

In Hungary, there is a certain particular contrast in historical settlement developments characteristic for the both great parts of the country (Transdanubia and the Great Hungarian Plain, the western and the eastern parts of the country, respectively). Settlement structure of historical villages and market-towns can be divided into two main groups on the basis of their morphological composition: There are mainly line-type settlements with conglomeratelike composition characteristic for the whole Transdanubian part of the country (therefore for the Small Hungarian Plain, the northern region of Transdanubia also), and many cluster-type settlements with double inlot composition characteristic for the Great Hungarian Plain (most of them being nearly round shaped) on the other side. Within both main groups, lots of subgroups can be distinguished. Certain subgroups are nowadays very difficult to recognise, owing to the settlement parts joined, annexed or built to the kernel in later times, also there are examples for the great extent modification and change of the historical settlement structure, as well.

Reasons for these disparate settlement developments typical on the Transdanubian and the Great Hungarian Plain regions, respectively, are - among others - the following features: different kind of economy applied in the middle ages (viz. advanced geoponical culture for the Transdanubian region, and in the contrary, dominant animal husbandry on double inlor settlements on the Great Hungarian Plain), different geomorphological features (the average relief height differences on settlements on the Great Hungarian Plain reach only half a metre, on the Small Hungarian Plain 2-3 metres, on the Transdanubian hilly settlements 5-10 metres, and on mountain settlements 50-100 metres), protection aspects (there were better defensible near-round shape settlements on the Great Hungarian Plain), as well as differentiated society structure (there was individual-like society on the Transdanubian region while forming more solidary, collective society against the Turk conquerors on the Great Hungarian Plain region), and on the Transdanubian region, effects of settlements traditions from the neighbouring countries, as well.

It is shown through investigations of historical settlements that main elements of ichnography of historical settlements thought as "unsubstantiated irregular" are, in many cases, determined by topographical features, and "being once and unreproducible" physiognomy of the settlements is partially drawn back to these characteristics. This recognition can stimulate settlement planners to better evaluation of the historical fibre of the settlements and contribute to the change of attitude of practical settlement planning as may be experienced even in our days. During development of settlements, the target is no more the protection of certain monument buildings or aggregations of buildings, certain streets or squares but integrated protection of the whole constructed settlement environment and the incorporating neighbouring natural landscape, together the so-called "character protection". 